\title{
NOTE
}

\section{THE LEGAL CONSEQUENCES OF FATLURE TO COMPLY WITH DOMESTICATION STATUTES}

Corporation $A$, doing business in various states throughout the country, has installed local agents for the transacting of its business in two adjacent states, $X$ and $Y$, neither of which is its state of incorporation. The local agent in $X$ makes a contract for the sale of the corporation's goods to a local buyer, who subsequently refuses to pay for them; in $Y$ the local agent deliberately withholds from the corporation monies collected for goods sold to local buyers. In a suit by the corporation against the buyer in $X$ recovery may be had if the corporation pays certain fees and files certain papers in that state; ${ }^{1}$ but recovery in the second action, for monies to which it would otherwise be equally entitled, is absolutely denied. ${ }^{2}$ Corporation $B$, similarly engaged in multistate commerce through local agents, requires all locally negotiated contracts for the sale of its goods to be accepted and verified by its office in its state of incorporation. When a buyer of its goods in one state defaults in payment, the corporation may sue in that state to collect the amounts due without filing or paying fees ${ }^{3}$ yet in another state the same business procedures may result in the corporation being brought into the court of each county in which its local agent dealt on its behalf, in an attempt to subject it to substantial fines for its conduct in each. . $^{4}$

Such diverse treatment of essentially identical conduct by a corporation doing business in a state other than that of its incorporation-a consequence of our federal system-is indicative of the problem facing any corporation venturesome enough to do business outside its state of incorporation. This same diversity accounts for the difficulties involved in any attempt to generalize as to the legal consequences attendant upon the failure of foreign corporations to comply with domestication statutes. ${ }^{5}$

\section{State Power To Require Domestication}

Today, multistate operation by a corporation is commonplace. This fact, coupled with the fictitious nature of corporate existence, presents

1 J. R. Watkins Co. v. Floyd, 119 So. $2 d 164$ (La. Ct. App. 1960).

2 J. R. Watkins Medical Co. v. Williams, 124 Ark. 539, 187 S.W. 653 (1916).

3 Alexander Film Co. v. Pierce, 46 N.M. 110, 121 P.2d 940 (1942).

4 Alexander Film Co. v. State, 201 Ark. 1052, 147 S.W.2d 1011 (1941).

5 For purposes of this Note, a "foreign" corporation is any private corporation for profit, exclusive of special-purpose corporations such as insurance or banking companies, which is incorporated in a state other than the one about whose domestication law a given controversy revolves. 
peculiar problems regarding the ability of a corporation to act beyond the bounds of the state giving it life-problems early posed by the Supreme Court's holding in Bank of Augusta $v$. Earle ${ }^{6}$ that a corporation was not entitled to the same ambulatory privileges as a citizen and could not freely do business beyond the geographical confines of its domicile. Despite the obvious fact that geographical lines are inherently unwieldly and unrealistic for determining legal controls over corporate activity-particularly in an economy as mobile as our own-the states have traditionally been quite free to pursue their own best interests by restricting the entrance of, requiring information from, governing the actions of, and assuring their share of revenue from, corporate entities created by sister sovereignties. ${ }^{7}$ It is the purpose of this Note to examine the legal incidents stemming from state exercise of this "exclusionary" 8 power today, and to appraise the efficacy of the various techniques employed in achieving state goals.

At the outset two observations must be made. First, a matter of delimitation. The registration or domestication of foreign corporations consists at least of filing certain documents regarding the corporate character, $^{9}$ paying fees for the privilege of doing business in the state, ${ }^{10}$ appointing someone in that state upon whom service of process can be made, ${ }^{11}$

838 U.S. (13 Pet.) 519 (1839).

7 Paul v. Virginia, 75 U.S. ( 8 Wall.) 168 (1868), established the basis for geographical influence by holding that the states may permit foreign corporations to do local business "upon such terms and conditions as those States may think proper to impose." Id. at 181 .

8 Though, technically, states have the power to "exclude" foreign corporations from doing business within their boundaries, it is very late in history to accept this formulation as realistic. See Note, The Adoption of the Liberal Theory of Foreign Corporations-(II) The Functional Capacity of a Foreign Corporation, 79 U. PA. L. Rev. 1119 (1931) ; Comment, 1961 Duke L.J. 274, 276-77.

9 E.g., PA. STAT. ANN. tit. 15, $\$ 2852-1004$ (Supp. 1960) (name of state of incorporation and information about share structure).

10 E.g., OHIo Rev. CODE ANN. $\$ 1703.09$ (Page 1954) (based on number of issued shares represented in the state). The failure either to file or to pay the tax can result in revocation of the certificate of authority to do local business. E.g., Conn. Gen. Stat. Rev. \$33-409 (Supp. 1959). But if no disability attends failure to meet these annual requirements, courts may be unwilling to penalize a corporation to the extent of allowing third parties to avoid contractual liability because of such failure. It has been explained that the omission of sanctions means that none was intended. Smith Rolfe Co. v. Wallace, 41 Okla. 643, 139 Pac. 248 (1914) ; cf. Portland Ass'n of Credit Men, Inc. v. Early, 42 Wash. 2d 273, 254 P.2d 758 (1953) (third party may not go behind state-issued certificate to demonstrate that insufficient fees were paid).

11 This requirement is found in every state and the District of Columbia. E.g., ARK. STAT. \$ 64-1201 (1957) (secretary of state or agent); D.C. CoDE ANN. \$\$ 29-933 (g)-(i) (Supp. 1960) (individual or corporation); N.J. STAT. ANN. \$ 14:15-3(c) (1939) (domestic corporation or natural person). Usually, appointment of an agent for service of process is one element of domestication, and failure to make such an appointment is covered by a general clause relating to disabilities for noncompliance. E.g., Mo. ANN. STAт. \$351.720 (1952). The statutory sanction has been applied even where the failure to appoint an agent has not been accompanied by any other domestication omissions. Wiley Elec. Co. v. Electric Storage Battery Co., 167 Miss. 842,147 So. 773 (1933). However, a defendant may, under some circumstances, be estopped from raising this defense. Eastlick v. Hayward Lumber \& Inv. Co., 33 Ariz. 242, 263 Pac. 936 (1928). A corporation may commonly be subjected to suit in a jurisdiction where it has done business, even though it has not expressly appointed an agent for service, for the doing of business without such an express appointment will be deemed an appointment of the secretary of state as its agent for this purpose. E.g., Orla. Stat. Ann. tit. 18, § 1.17 (1953). 
ard perhaps repeating some of these acts in the specific county in which the corporation intends to settle. ${ }^{12}$ Insofar as the purposes of these requirements vary, it would be possible for state legislatures to provide various disabilities or penalties for noncompliance. Or, absent such express directions, it would not be surprising to find the judiciary suiting a particular punishment to a particular form of noncompliance. In fact, such legislative and judicial efforts are common. ${ }^{13}$ For purposes of this Note, however, only complete failure to do any of the acts required by local law will be classed as noncompliance. Any partial compliance, and the nature of it, will be clearly labeled. Second, a matter of jurisdiction. There lingers in this field a problem stemming from our parallel system of federal and state courts. Before Erie R.R. v. Tompkins ${ }^{14}$ it was possible for a foreign corporation denied access to state courts for the enforcement of its claims to turn to the federal courts to secure the desired relief, provided the necessary jurisdictional requirements were met. ${ }^{15}$ Now, however, in cases based on diversity of citizenship, each federal court is to apply the law of the state in which it sits, including the statute barring a foreign corporation from suit. ${ }^{16}$ Thus, the policies of the state evinced through the domestication laws and their interpretation are recognized and respected by the federal judiciary.17

Before attempting to explore the effects of noncompliance, inquiry must focus on the kinds of conduct that require a corporation to qualify to do business in a state other than that of its incorporation, the kinds of conduct that will subject a foreign corporation to the jurisdiction of such a state, variations among the statutes, according to their purposes, as to the degree and intensity of conduct required, and constitutional limitations on the ability of states to deal with intruding foreign corporations. These issues have been raised so repeatedly that the principles generally applied in resolving them are readily available. Unfortunately, however, both principles and resolutions serve more to label a result than to explicate the rationale for achieving it.

A foreign corporation going into a state and erecting a manufacturing plant for the local production, distribution, and sale of its goods would clearly be required to domesticate. Its conduct would amount to "doing (1959).

12 E.g., IDAho Code Ann. §30-501 (Supp. 1961); Wxo. Stat. Anv. \$17-33

13 See, e.g., Association Collectors, Inc. v. Hardman, 2 Wash. $2 \mathrm{~d}$ 414, 98 P.2d $318(1940)$.

14304 U.S. 64 (1938).

15 David Lupton's Sons Co. v. Automobile Club of America, 225 U.S. 489 (1912).

18 Woods v. Interstate Realty Co., 337 U.S. 535 (1949). Compare Hicks Body Co. v. Ward Body Works, Inc., 233 F.2d 481 (8th Cir. 1956), with Hunter Packing Co. v. Trinity Universal Ins. Co., 98 F. Supp. 215 (E.D. Ill. 1948). Diversity of citizenship accounts for the majority of cases that reach federal courts in regard to these matters, often by removal from state courts.

${ }_{17}$ See Note, Jurisdiction of Federal District Courts Over Foreign Corporations, 69 Harv. L. REv. 508, 520-24 (1956) ; cf. Angel v. Bullington, 330 U.S. 183, 191-92 (1947). 
business" locally and it would be subject to the jurisdiction of local courts. The state has a legitimate interest in making certain demands of a corporation engaged, or proposing to engage, in "intrastate activities" before allowing it to take advantage of local facilities for police protection, to draw on the local labor force, to contract with local citizens and concerns, to use the state courts, and to do all those things that a local association, similarly situated, would not be entitled to do without complying with the analogous requirements for domestic incorporation. ${ }^{18}$ At the other extreme, it is almost as clear that a corporation which receives by mail from an out-ofstate citizen, at its office in its state of incorporation, a single order for a particular item, which it then mails to that buyer, would not have to comply with the domestication laws of that state as a condition precedent to suing the buyer and would probably not be amenable to service of process in the buyer's state. For these purposes it has done no business in that state. Between these extremes lies the factual ${ }^{19}$ continuum on which may be placed countless decisions ${ }^{20}$ that must face the question of whether certain conduct constitutes "intrastate business" 21 or "doing business" 22 or "not

18 See Hill-Lanham, Inc. v. Lightview Dev. Corp., 163 F. Supp. 475 (D.D.C. 1957). An excellent expression of one aspect of the state's interest in domestication is the following dictum from Travelers Fire Ins. Co. v. Ranney-Davis Mercantile Co., 173 F.2d 844, 847 (10th Cir.), cert. denied, 337 U.S. 930 (1949) :

A11 legislation making foreign corporations amenable to judicial process in the state in which they seek the privilege of doing business is predicated upon the right of the state to protect its citizens in their controversies with such corporations by requiring that the same be adjudicated in the courts of the state rather than compelling its citizens to travel to remote places to litigate such controversies.

19 Whether a corporation is doing business within the terms of a local domestication statute is always a question of fact. E.g., Brown v. Farmer \& Ochs Co., 209 F.2d 703, 706 (6th Cir. 1954).

20 "The published decisions on what constitutes 'doing business' in a State by a foreign corporation are literally legion." Echeverry v. Kellogg Switchboard \& Supply Co., 175 F.2d 900, 902 (2d Cir. 1949).

21 Held to constitute intrastate activity so as to bar the action of plaintiff corporation: Cohn-Hall-Marx Co. v. Feinberg, 214 Minn. 584, 8 N.W.2d 825 (1943) (contract; negotiations leading to contract carried on by resident agent); Case v. Mills Novelty Co., 187 Miss. 673, 193 So. 625 (1940) (replevin; local servicing of machine sold) ; United Artists Corp. v. Board of Censors, 189 Tenn. 397, 225 S.W.2d 550 (1949), cert. denied, 339 U.S. 952 (1950) (judicial review; foreign corporation sharing in profits from local exhibition); Holleb Liquor Distribs., Inc. v. Lincoln Fireproof Warehouse Co., 223 Wis. 231, 270 N.W. 545 (1936) (conversion; contract of assignment of converted property to foreign corporation made in state after property had come to rest there).

22 While there appears to be no legal significance in the phrase used- "intrastate," "local," or "doing business"-a distinction may be noted between the amount of local activity that will be "doing business" for service of process on a foreign corporation or for substituted service on the secretary of state, and the sometimes greater amount that will require the corporation to domesticate in order to maintain a suit. See Keane \& Collins, Changing Concepts of What Constitutes "Doing Business" by Foreign Corporations, 42 MARQ. L. Rev. 151, 160-62 (1958); 26 GEO. WASH. L. REv. 735, 737 n.21 (1958). Compare Toedman v. Nooter Corp., $180 \mathrm{Kan} .703,308$ P.2d 138 (1957), and Malavasi v. Villavecchia, 62 N.J. Super. 510, 163 A.2d 214 (Super. Ct. 1960), zerith William L. Bonnell Co. v. Katz, 23 Misc. 2d 1028, 196 N.Y.S.2d 763 (Sup. Ct. 1960), and Knight Prods., Inc. v. Donnen-Fuel Co., 20 N.Y.S.2d 135 (Sup. Ct. 1940).

The difference between forbidding access by foreign corporations to the court of the state, because of their failure to comply with the statutory 
doing business" 23 for the particular issue being litigated. "[D] etermina-

provisions for doing business therein, and . . . providing for service on a designated agent where, without complying with the statute, they undertake to do business in the state . . . is that, while the former is strictly construed so that the exclusion from access to the courts of the state requires a strong showing that the statute has been violated, the latter is liberally construed since otherwise citizens of the state would be forced to resort to another jurisdiction in order to maintain suits ....

Mississippi Wood Preserving Co. v. Rothschild, 201 F.2d 233, 236 (5th Cir. 1953). And again, what would be sufficient to require domestication might be inadequate to subject the corporation to penalties for noncompliance. Compare State ex rel. Independence County v. Tad Screen Advertising Co., 199 Ark. 205, 133 S.W.2d 1 (1939) (penalty recoverable where interstate acts are "incidental" to intrastate activity), with Murray Tool \& Supply Co. v. State, 203 Ark. 874, 159 S.W.2d 71 (1942) (statute should not be used unless it is quite clear that acts constitute doing business). The quality or quantity of acts done locally which are sufficient to allow service of process in one form or another have been exhaustively discussed, see, e.g., McMenomy v. Wonder Bldg. Corp. of America, 188 F. Supp. 213 (D. Minn. 1960); Gearhart v. WSAZ, Inc., 150 F. Supp. 98 (E.D. Ky. 1957), aff'd, 254 F.2d 242 (6th Cir. 1958), and will not be elaborated here. The most important recent case is International Shoe Co. v. Washington, 326 U.S. 310 (1945). That case effectively abandoned all former constitutional tests for determining the validity of a state's assertion of jurisdiction over corporations and substituted the criterion of "certain minimum contacts . . . such that the maintenance of the suit does not offend 'traditional notions of fair play and substantial justice." Id. at 316. The examples of activity required for service of process in this and the following footnote may provide a basis for comparison with the activity requiring compliance with domestication laws, but, as will be seen, clear lines of demarcation can scarcely be said to exist.

Held to constitute doing business for service of process: Republic Supply Corp. v. Lewyt Corp., 160 F. Supp. 949 (E.D. Mich. 1958) (distributor contract with copromotion and local control); Ultra Sucro Co. v. Illinois Water Treatment Co., 146 F. Supp. 393 (S.D.N.Y. 1956) (local office); De Golia v. Twentieth Century-Fox Film Corp., 140 F. Supp. 316 (N.D. Cal. 1954) (activity of coconspirators); McClanahan v. Trans-America Ins. Co., 149 Cal. App. 2d 171, 307 P.2d 1023 (Dist. Ct. App. 1957) (investigating and defending suits); Malavasi v. Villavecchia, supra (local product test); Arco Welding \& Mach. Works, Inc. v. Terry Contracting, Inc., 44 N.J. Super. 586, 131 A.2d 316 (Super. Ct. 1957) (signing a contract); Eclipse Fuel Eng'r Co. v. Superior Court, 148 Cal. App. 2d 736, 307 P.2d 739 (Dist. Ct. App. 1957) (dictum) (substantial regular business through agency or independent contractor).

Held to constitute doing business so as to require presuit domestication: Davis v. Asano Bussan Co., 212 F.2d 558 (5th Cir. 1954) (unloading and selling distress cement); Midwest Sportswear Mfg. Co. v. Baraboo Chamber of Commerce, 161 F.2d 918 (7th Cir. 1947) (executing a contract); In re Bell Lumber, 149 F.2d 980 (7th Cir. 1945) (hiring local architects and supervising construction); Reliance Fertilizer Co. v. Davis, 124 Fla. 859, 169 So. 579 (1936) (sales through local agents); Thomas v. Hudson Sales Corp., 204 Md. 450, 105 A.2d 225 (1954) (supervision and control of car sales and service); Viking Equip. Co. v. Central Hotel Co., 230 Mo. App. 304, 91 S.W.2d 94 (1936) (installation of sprinkler system); Manhattan Terrazzo Brass Strip Co. v. A. Benzing \& Sons, 72 Ohio App. 116, 50 N.E.2d 570 (1943) (establishment of local corporation to merchandise as agent). The performance of the duties of an assignee for the benefit of creditors would constitute doing business locally. Crites v. Associated Frozen Foods Packers, 190 Ore. 585, 227 P.2d 821 (1951).

23 Held not to constitute doing business for service of process: Anderson v. British Overseas Airways Corp., 144 F. Supp. 543 (S.D.N.Y. 1956) (cosubsidiary's presence within state not defendant's); Reed v. Real Detective Publishing Co., 63 Ariz. 294, 162 P.2d 133 (1945) (consignment sales with factoring arrangement); Victory Carriers, Inc. v. Hawkins, 352 P.2d 314 (Hawaii 1960) (local representation without agency contract); Arundel Crane Serv., Inc. v. Thew Shovel Co., $214 \mathrm{Md}$. 387, 135 A.2d 428 (1957) (local sale through independent dealer); Zeidler v. Johnson, 346 Mich. 203, 77 N.W.2d 756 (1956) (corporation president lives within state and confers about company matters there); Garber v. Bancamerica-Blair Corp., $205 \mathrm{Minn}$. 275,285 N.W. 723 (1939) (independent subsidiary within state plus local phone listing). Compare N.C. GEN. STAT. \$55-145(b) (1960), which purports to make a foreign parent subject to service through the local subsidiary, with Fitzgerald v. 
tion of the applicable rule presents no serious difficulty. Application of the rule to given facts, however, often does." 24

Increasingly legislatures are attempting to lighten the judicial load by statutes declaring that certain acts do not constitute doing business so as to require domestication ${ }^{25}$ or equating certain conduct with a doing of local business for amenability to service of process. $^{26}$ The utility or necessity of the former may be questioned where they comprise no more than existing precedents ${ }^{27}$ or a list of activities which no court today would seriously consider sufficient to require domestication. ${ }^{28}$ And the success of the jurisdiction statutes in reducing litigation is questionable if Minnesota's experience is illustrative, ${ }^{29}$ for attempts to extend jurisdiction to the constitutional limits may raise new problems for the courts without providing automatic answers to the old.

There are several principles which serve to limit the exercise of state power over foreign corporations with respect to domestication requirements. One, based on the commerce clause of the federal constitution, is that

Hilton Hotels Corp., 183 F. Supp. 342 (E.D. Pa. 1960), which held a parent corporation cannot be served to gain jurisdiction over an independent foreign subsidiary. Held not to constitute doing business so as to require presuit domestication: Hieston v. National City Bank, 132 Md. 389, 104 Atl. 281 (1918) (bringing suit); Dratz v. Occidental Hotel Co., 325 Mich. 699, 39 N.W.2d 341 (1949) (intercorporate consolidation arrangement drawn up in state); Whitney v. Dudley, 40 N.Y.S.2d 838 (Sup. Ct.), aff'd, 266 App. Div. 1056, 45 N.Y.S.2d 725 (1943) (execution and mailing of contract); Knight Prods., Inc. v. Donnen-Fuel Co., 20 N.Y.S.2d 135 (Sup. Ct. 1940) (shipping coal into state and storing there); Taylor v. State, 29 Wash. 2d 638, 188 P.2d 671 (1948) (bringing suit for declaratory judgment); Niblack v. Seaberg Hotel Co., 42 N.M. 281, 76 P.2d 1156 (1938) (acting as trustee) (dictum). "[I]t is the exercising of its corporate franchises and maintenance of a place of business within the state in the sense that corporations organized and doing business under the laws of this state maintain such places of business ..."William L. Bonnell Co. v. Katz, 23 Misc. 2d 1028, 1031, 196 N.Y.S.2d 763, 767 (Sup. Ct. 1960).

24 Beck v. Spindler, 256 Minn. 543, 552, 99 N.W.2d 670, 677 (1959).

25 E.g., Alaska Comp. Laws Ann. \$36-2A-141 (Supp. 1958); Conn. Gen. Stat. ANN. \$ 33-397(b) (Supp. 1959); N.D. Cenr. Code \$ 10-22-01 (Supp. 1961). ${ }^{26}$ E.g., N.C. Gen. Stat. \$ 55-145 (1960) ; VT. Stat. ANn. tit. 12, §854 (1958). 27 See Comment, 32 Texas L. Rev. 211, 213 (1954).

28 E.g., Oregon lists the following: (1) maintaining or defending an action or arbitration or settling a suit; (2) holding directors' meetings or other internal corporate activities; (3) maintaining bank accounts; (4) keeping transfer offices for security dealings; (5) making sales through independent contractors; (6) soliciting orders which become binding outside the state; (7) creating mortgages or liens; (8) enforcing property rights; (9) doing interstate business; (10) engaging in isolated transactions. ORE. Rev. STAT. \& 57.655(2) (1959).

29 Minnesota added a new section to its statute in 1957 which reads as follows: "If a foreign corporation makes a contract with a resident of Minnesota to be performed ... in Minnesota, or if such foreign corporation commits a tort . . in Minnesota against a resident of Minnesota, such acts shall be deemed doing business in Minnesota...." Mrnn. Stat. Ann. \$303.13(3) (Supp. 1960). So far the following cases have attempted to construe the statute: Hutchinson v. Boyd \& Sons Press Sales, 188 F. Supp. 876 (D. Minn. 1960); McMenomy v. Wonder Bldg. Corp. of America, 188 F. Supp. 213 (D. Minn. 1960); Dahlberg Co. v. American Sound Prods., Inc., 179 F. Supp. 928 (D. Minn. 1959) ; Mueller v. Steelcase, Inc., 172 F. Supp. 416 (D. Minn. 1959); Paulos v. Best Sec., Inc., 109 N.W.2d 576 (Minn. 1961); Adamek v. Michigan Door Co., 108 N.W.2d 607 (Minn. 1961); Dahlberg Co. v. Western Hearing Aid Center, 107 N.W.2d 381 (Minn.), cert. denied, 366 U.S. 961 (1961) ; Atkins v. Jones \& Laughlin Steel Corp., 258 Minn. 571, 104 N.W.2d 888 (1960); Beck v. Spindler, 256 Minn. 543, 99 N.W.2d 670 (1959). 
states cannot unduly burden interstate commerce. ${ }^{30}$ Another, relating to federal supremacy, is that federal corporations are not "foreign" and therefore fall outside the purview of these state statutes. ${ }^{31}$ A third, largely derived from older precedents, is that the doing of a single act or isolated transaction will not amount to the doing of business sufficient to require domestication. ${ }^{32}$

Despite the fascinating subtlety or bewilderment with which these rules may be applied, their interpretation and interplay are not the subject of this Note. Out of the annual plethora of cases, this Note shall concern itself with those that preliminarily find the corporation has acted in such a way as to come within the state's regulatory jurisdiction and that are not disposed of on the basis of some self-limitation on that jurisdiction.

\section{Penal and Injunctive Sanctions}

State legislatures commonly provide for a fine to be levied upon a foreign corporation for either engaging in local business before domestication $^{33}$ or failing to file the requisite documents. ${ }^{34}$ Provision is ordinarily made for some state official to bring suit to collect the penalty amounts, and, short of a defense that the corporation was not doing business in the state at all, $^{35}$ few problems are ever encountered in the process. ${ }^{36}$

30 See Sioux Remedy Co. v. Cope, 235 U.S. 197 (1914) ; Palmer v. Aeolian Co., 46 F.2d 746 (8th Cir.), cert. denied, 283 U.S. 851 (1931); Stokely-Van Camp, Inc. v. Hackert, 80 F. Supp. 837 (S.D. Iowa 1948); Weber Showcase \& Fixture Co. v. Co-ed Shop, 47 Ariz. 415, 56 P.2d 667 (1936). Compare Cadden-Allen, Inc. v. TransLux News Sign Corp., 254 Ala. 400, 48 So. 2d 428 (1950), with Loudenville Milling Co. v. Davis, 251 Ala. 459 , 37 So. 2d 659 (1948).

31 E.g., Bezat v. Home Owners' Loan Corp., 55 Ariz. 85, 98 P.2d 852 (1940).

32 See Monaghan \& Murphy Bank v. Davis, 27 Ariz. 532, 234 Pac. 818 (1925); Crockin v. Boston Store, 137 Fla. 853, 188 So. 853 (1939) ; Reynolds Offset Co. v. Summer, 58 N.J. Super. 542, 156 A.2d 737 (Super. Ct. 1959), certification denied, 31 N.J. 554, 158 A.2d 453 (1960). The extension of judicial jurisdiction on the basis of a single act, see Note, Single Act Statutes and Jurisdiction Over Foreign Corporations, 43 VA. L. REv. 1105 (1957), may indicate that this principle is on the wane. (1947)

33 E.g., ALA. Code tit. 10, $\$ 21(92)$ (Supp. 1959) ; MrNn. Stat. ANN. $\$ 303.20$

34 E.g., Ark. Stat. §64-1202 (1957) ; Fla. Stat. AlnN. §613.11 (1956); Hawair REV. LAws $\$ 174-10$ (1955). The significance of the difference between these two types of statutes is illustrated by Kentucky Straight Creek Coal Co. v. Commonwealth, $304 \mathrm{Ky} .247,200$ S.W.2d 470 (1947), in which venue was determined by the place of doing business because the violation was the doing of business and not, as defendant urged, the failure to file.

35 Although the concept of doing business may be stretched or abandoned where the issue is the validity of service of process and the court's exercise of judicial jurisdiction, see Note, supra note 32, when it comes to construe this kind of penal statute, a court may be inclined toward a more rigorous construction, see Murray Tool \& Supply Co. v. State, 203 Ark. 874, 159 S.W.2d 71 (1942). But cf. State ex rel. Independence County v. Tad Screen Advertising Co., 199 Ark. 205, 133 S.W.2d 1 (1939). See generally 17 Fletcher, Private Corporations \& 8515 (rev. vol. 1960).

36 Defenses based on technical defects in the statutes have frequently been asserted, seldom successfully. Corporations have vainly contended that suit was improperly brought by a city solicitor where the statute required its institution by the county solicitor, Tennessee Mutual Bldg. \& Ioan Ass'n v. State, 99 Ala. 197, 13 So. 687 (1892), that criminal rather than civil procedure was required by a statute subjecting noncomplying foreign corporations to a "fine," State ex rel. Jones v. Howe Scale Co., 
The fines imposed on noncomplying foreign corporations vary in amount ${ }^{37}$ and as to the basis according to which they are calculated. ${ }^{38}$ Obviously they serve both a revenue and-depending upon the size of the fine-a deterrent function. ${ }^{39}$ But it must be recognized that the deterrent effect of any fixed penalty is inversely proportional to the size of the corporation involved. A large fine may well serve to filter out small, financially tenuous corporations. So far as domestication's informational function is concerned this selective deterrence might provide adequate protection for local citizens, as the financial soundness of larger companies can often be ascertained by potential creditors despite a failure to file locally. Furthermore, the greater resources of these companies assure a margin of security against the eventuality of litigation with local citizens. Nevertheless, ten states ${ }^{40}$ and the District of Columbia ${ }^{41}$ have recently enacted statutes assessing an amount equal to the fees and franchise taxes

182 Mo. App. 658, 166 S.W. 328 (1914), and that the proceeding was illegal because the penalties collected were to become a part of the state's general funds, State ex rel. Lay v. Arthur Greenfield, Inc., 205 S.W. 619 (Mo. 1918). On the other hand, a recodification of state law may provide an opportunity to preclude the state from asserting penalties accrued under the old statute if the new law is an effective repeal by substitution, rather than a mere cumulation, of the old provisions. See State ex rel. Williamson v. Empire Oil Corp., 353 P.2d 130 (Okla. 1960). See also Opinion of Arizona Attorney General, March 24, 1959, 2 CCH CoRp. L. GuIde II 9919 (June 9, 1959), construing ARIz. REv. Stat. $\S 10-104$ (Supp. 1960). The use of this distinction to justify excusing prior illegal conduct is unconvincing where there is, for example, a revision of the penal amount from a set figure to a range which includes the prior amount as the upper limit. See People v. Crucible Steel Co. of America, 150 Mich. 563,114 N.W. 350 (1907). However, an unexpressed factor in such decisions may be judicial reluctance to permit the possibility of the state ignoring prolonged illegal conduct in order to assess at some later date a more sizable penalty. (In People v. Crucible Steel Co. of America, supra, the penalty under the old statute, mounting at the rate of $\$ 1,000$ per month, totaled $\$ 61,000$ by the time of trial.) So confined, the policy reasons for forgiving prior illegalities would be absent in cases in which the state had not been lax for an unreasonable length of time. Then the state should be entitled to recover despite the corporate defendant's subsequent compliance with the domestication statute, see State ex rel. Nelson v. S. P. Pond Co., 135 Mo. App. 81, 85, 115 S.W. 505 (1909) ("Subsequent obedience to temporal laws does not pardon prior violations. That is a divine law, but corporations having no souls to save [citing Blackstone] . . . have neither necessity nor right to invoke it."), or a legislative redefinition of the illegality and its accompanying penalties.

37 See Del. Code ANn. tit. 8, §349 (1953) (range) ; Mo. Ann. Cone art. 23, § 91 (d) (1957) (flat sum); NEv. REv. StAT. \$80.210 (1957) (specified minimum); N.H. Rev. Stat. ANn. \$300:7 (1955) (specified maximum). Compare Ga. Code ANN. $\$ 22-1506$ (Supp. 1958) ( $\$ 100$, remittable upon subsequent compliance if original noncompliance was innocent), with IND. ANN. STAT. \$25-314 (1960) (up to \$10,000).

38 See Kx. Rev. Stat. \$271.990(2) (1959) (calculated per offense); S.C. CoDE $\$ 12-737$ (1952) (calculated per diem); Tex. Bus. CoRp. Acr art. 8.18 (1956) (calculated per month).

39 Of course, many of the activities that violate local statutes are such isolated transactions that qualification might reasonably have been thought to be unnecessary. Little deterrent effect will exist under these circumstances, no matter how large the penalty.

40 Alaska Comp. Laws ANn. \$\$36-2A-159 (Supp. 1958); Colo. Sess. Laws 1959 , ch. 83, \$119(3); ConN. GeN. STAT. Rev. \$33-412(c) (Supp. 1959); ILL. ANN. StaT. ch. 32, § 157.125 (Smith-Hurd 1954); N.C. Gen. STat. \$ 55-154(c) (1960); N.D. Cent. Code $\$ 10-22-19$ (1960) ; OkLA. Stat. AnN. tit. 18, § 1.201 (b) (1953) ; Ore. Rev. Stat. \$ 57.745(3) (1959) ; Tex. Rev. Civ. Stat. Ann. art. 8.18(c) (1956); Wis. Stat. ANn. \$ 180.847 (3) (1957).

41 D.C. Cone ANN. §29-934f(c) (Supp. 1959). 
which would have been imposed had the corporation qualified upon first entering the state, plus either some further small penalty or a percentage of the accrued amount. This is a logical way to calculate the amount of the corporation's liability and, insofar as the penalty varies directly with the offender's size, it will, unlike a fixed fine, bar both large and small foreign entities with equal selectivity.

Either in conjunction with or in lieu of the imposition of a fine, the state may label the conducting of precompliance business a misdemeanor. ${ }^{42}$ No special consequences ordinarily flow from this appellation..$^{43}$

A few jurisdictions give the state attorney general standing to sue out an injunction against further local activity by an undomesticated foreign corporation. Vermont has tempered this by authorizing discontinuance of such a suit upon subsequent compliance by the corporation. ${ }^{45}$ This restraint is consistent with the use of these laws to compel disclosure of relevant information rather than to punish or banish the offending corporation; it may also indicate a recognition that many, if not most, violations are unwitting. The same policy is evident in the many statutes providing for the reinstatement of a foreign corporation denied the privilege of carrying on local activity if it subsequently complies. ${ }^{46}$

\section{Disabilities}

The most important of the possible consequences of a foreign corporation's failure to domesticate is the likelihood that it will be denied access to the state's courts or find its obligations in that state impaired. The insecurity injected into normal business activities by the threat of unenforceability usually provides a sufficient incentive to domesticate. ${ }^{47}$

42 E.g., ArA. Code tit. 10, §21(94) (Supp. 1960) ; Mont. Rev. Codes ANN. §15-1705 (1955); PA. Stat. AnN. tit. 15, § 2852-1014 (1958).

43 But see Hutterian Brethren v. Haas, 116 F. Supp. 37 (D. Mont. 1953), discussed in note 149 infra.

44 Mass. Gen. Laws Ann. ch. 181, § 19 (1955) ; N.H. Rev. Stat. Ann §300:7 (1955); N.Y. GEN. CoRP. LAW \$219; VT. StAT. ANN. tit. 11, \$861 (1958). The Massachusetts statute authorizes an injunction only "until compliance," whereas the New Hampshire provision, clearly labeled a "penalty," seems to permit a permanent injunction against all further business in the state by the offending corporation, notwithstanding any possible later willingness to domesticate. The authorized scope of injunctions under the other two statutes is problematical, and there is no case law to shed light on the question. Where there is no statute giving injunctive powers for the specific purpose of banishing undomesticated foreign corporations, the same result might be achieved by quo warranto, see State ex rel. Attorney General v. Western Mut. Life \& Acc. Soc'y, 47 Ohio St. 167, 24 N.E. 392 (1890) (dictum), although there seems to be no reported case in which the writ was employed successfully to oust a foreign corporation whose sole offense was failure to domesticate, except perhaps State ex rel. Crossland v. Omaha \& C.B. Ry. \& B., 91 Iowa 517, 60 N.W. 121 (1894), in which the corporation was given 60 days to comply or be ousted.

45 VT. Stat. Ann. tit. 11, \$ 862 (1958).

46 See, e.g., Nev. Rev. Stat. $\$ 80.170$ (Supp. 1959); OHto Rev. Code ANk. $\$ 1703.29$ (B) (Page 1954). Significantly, Vermont has no such procedure. Compare text accompanying note 45 supra.

47 The inability to enforce contracts "in what may be the only jurisdiction in which defendant is amenable to service of process, is a substantial penalty indeed." Unlicensed Foreign Corporations-Enforcement of Contracts, 23 CoRp. J. 23 (1960). 
Ignoring minor verbal differences, this kind of state control of precompliance commercial activity today consists of enactments that (1) declare all acts by an undomesticated foreign corporation void, ${ }^{48}$ (2) bar all suits by an offending corporation on transactions arising out of such activity, ${ }^{49}$ (3) withhold the right to maintain any action on intrastate transactions until compliance, ${ }^{50}$ or (4) deny access to the courts for any purpose until compliance. ${ }^{51}$ Two common supplementary provisions preserve the right to defend suits while declaring precompliance contracts not invalid ${ }^{52}$ and set the same disabilities upon assignees of any right or claim as apply to the foreign assignor. ${ }^{53}$

There are a limited number of factual contexts in which undomesticated corporations have most commonly invoked state judicial processes only to be denied relief because of the operation of these laws.

\section{A. Contract Actions}

An undomesticated foreign corporation which brings suit for amounts due under a contract with a local domiciliary is apt to be met at the outset with a motion to dismiss or its local equivalent. ${ }^{54}$ Though an obvious injustice will result from defendant's retention of plaintiff's performance if the motion is granted, ${ }^{55}$ the defendant may prevail on the ground that

48 ArIz. Rev. Stat. ANN § 10-482 (1956).

49 E.g., N.Y. GEN. CoRP. LAw $\$ 218$ (contracts made locally before compliance cannot be enforced by corporation or any successor in title or any person claiming under such successors or under either); UTAF CODE ANN. \$16-8-3 (1953) (contracts made in, or to be performed in, state before compliance wholly void at suit of corporation or its assignees); VT. STAT. ANN. tit. 11, $\$ 764$ (1958) (contracts made locally before compliance cannot be enforced by corporation, its assignees, or persons claiming under assignee or corporation; however this does not bar suit by domestic receiver of such corporation).

50 E.g., Alaska Comp. Laws Ann. \$36-2A-159 (Supp. 1958); Cal. Corp. Code \$6801; Fla. Stat. ANN. \$613.04 (1956); OHIo Rev. CoDe ANN. \$1703.29(A) (1953).

51 E.g., Hawarr Rev. Laws $\$ 174-10$ (1955) ("shall not be entitled to sue, plead or appear. . . for any cause of action whatever" during noncompliance).

52 E.g. Conn. Gen. Stat. Rev. \$33-412(b) (Supp. 1959); Ill. AnN. Stat. ch. $32, \$ 157.125$ (Smith-Hurd 1954).

53 E.g., Fla. Stat. AnN. $\$ 613.04$ (1956); S.D. Code $\S 11.2103$ (1939); see note 68 infra.

54 Almost without exception the violation of the domestication laws must be raised by the defendant. E.g., Western Loan \& Bldg. Co. v. Elias Morris \& Sons Co., 43 Ariz. 88, 29 P.2d 137"(1934). Even a certificate from the secretary of state averring noncompliance has been held unacceptable to raise the issue, the court refusing to take judicial notice of the fact of noncompliance. Pekin Cooperage Co. v. State ex rel. Pike County, 197 Ark. 341, 122 S.W.2d 468 (1938).

55 Note that this is not a judgment on the merits and has no res judicata effect. In Admiral Corp. v. Trio Television Sales \& Serv., 138 Colo. 157, 330 P.2d 1106 (1958), a suit which had been abated for noncompliance was held not to bar a subsequent suit. The dissent argued that it should be res judicata because dismissal came after the evidence was in and after the merits had been considered. However, the majority position seems correct inasmuch as the court grounded its dismissal specifically on noncompliance.

Some state courts have thought that dismissal was too harsh and have applied an equitable estoppel against a defendant retaining the contract benefits. See cases collected in 17 Fietcher, Private Corporations $\$ 8519$, at 728 n.34 (rev. vol. 1960). 
plaintiff, having chosen to do business in violation of local law, is not entitled to use local courts for the resolution of difficulties arising from this unlawful conduct. This rationale raises several interesting problems. Does it matter where the contract was made or performed, or where payment was to be made? Will the courts of other states allow this corporation to obtain relief if defendant can properly be served therein? Finally, how much freedom for judicial interpretation is provided by the words of the particular statute being applied?

Some older statutes declared contracts or acts by undomesticated corporations "void," 56 but the difficulties and uncertainties attending this classification have led most legislatures to prescribe the consequences of noncompliance in more detail; today only Arizona has an all-acts-void statute..$^{57}$ Such a provision is apt to leave foreign corporations totally without remedy with respect to its intrastate commercial transactions. ${ }^{58}$ Probably the strongest impetus for the abandonment of this terminology was the fluid meaning of the word "void." The term's strict application could conceivably boomerang to the serious detriment of those whom the statute was intended to protect.59 Even if this does not occur, the protection of local interests hardly seems to require the total nullification of

The argument for refusing to apply estoppel, based on the policy of prohibitory statutes, is presented in id. at 732. After an extensive review of the authorities, the Delaware high court refused to allow a defendant to retain benefits where plaintiff's omission consisted of a failure to appoint a statutory agent. Model Heating Co. v. Magarity, 25 Del. 459, 81 Atl. 394 (1911). "[A] different construction would open an avenue of easy escape to the dishonest debtor, and produce in many cases a harsh result, especially where the default might be due to oversight and neglect, rather than intentional wrong." Protective Fin. Corp. v. Glass, 100 N.J.L. 85, 87, 125 Atl. 879, 880 (Sup. Ct. 1924).

56 See 17 Fletcher, Prtvate Corporations $\$ 8509$ (rev. vol. 1960); Note, The Enforcibility of Contracts of Unlicensed Foreign Corporations, 25 CoLUM. L. REv. 806,807 (1925). The term "void" was occasionally read into statutes which did not speak to this question directly. E.g., Pittsburgh Constr. Co. v. West Side Belt R.R., 154 Fed. 929 (3d Cir. 1907).

57 Ariz. Rev. Stat. ANn. \$ 10-482 (1956).

58 The corporation's dilemma may be given an extra edge where the local courts read into the provision a manifestation of the state's "public policy." See National Union Indem. Co. v. Bruce Bros., 44 Ariz. 454, 38 P.2d 648 (1934). The phrase is so vague that it can justify almost anything. For example, continued enforcement of a disability after a statutory amendment which left the sanction unexpressed was explained in terms of public policy, the court refusing to find a repeal by implication from an increase in the penalty. Hicks Body Co. v. Ward Body Works, Inc., 233 F.2d 481 (8th Cir. 1956).

However, under such a statute, a foreign corporation need not fear that its contracts will be open to attack by all third parties who may be affected by them. See St. Avit v. Kettle River Co., 216 Fed. 872 (8th Cir. 1914) ; Hayden v. Dallas County, 143 S.W.2d 990 (Tex. Civ. App. 1940).

59 To say that the legislature intended the statute to render void contracts made without complying with it is to say that the legislature intended that if a foreign company should write life insurance in this state it might take the premiums, and then, upon the death of the person insured, refuse to pay the policies; and it is to say that a farmer of this state may purchase a machine or a herd of cattle from a nonresident corporation on credit, secure the price by chattel mortgage, refuse to pay, and then defeat an action of replevin for the property. Such an interpretation might attract the enthusiastic admiration of the highwayman, but it has nothing to commend itself to a court of justice.

State v. American Book Co., 69 Kan. 1, 17, 76 Pac. 411, 416, appeal dismissed, 193 U.S. 49 (1904). 
agreements consciously undertaken. If the concept of nullification were taken seriously, an otherwise innocent foreign corporation could as well be swindled by an angling domiciliary as vice-versa, voidness being mutual. Finally, such a provision allows excessive judicial discretion, as nothing inherent in the term makes certain the consequences which will follow from its application. ${ }^{60}$ Even changes in phraseology have not always been successful in eliminating the disquieting features. In Missouri, where the courts had for years interpreted the legislative pronouncement to mean that precompliance contracts were incurably void, ${ }^{61}$ a new statute was passed barring suits "while the requirements . . . [are] not complied with." 62 The first decision under this amendment failed to find in it any intent to change the status of contracts. The court concluded that if the legislature had sought to validate contracts it would have added a separate provision to that effect, as had the Illinois legislature, whose enactment supposedly had been this statute's model. ${ }^{63}$ Precompliance contracts were still void in Missouri. Not until twelve years and some criticism ${ }^{64}$ later was this result cast in doubt by a Missouri lower court decision which demonstrated what should have been a discernible proposition all alongthat the legislature meant to change the law by changing the words. ${ }^{65}$

Where a statute imposes fines for noncompliance and there is no express provision concerning the maintenance of contract actions, the courts have often held the penal amount to be exclusive and have refused to impose additional disabilities. ${ }^{86}$ But where the legislature has decreed contracts unenforceable and an undomesticated corporation sues to enforce performance, no rule of interpretation and no undesirable incidental effects deter the courts' rigorous application of the statute. ${ }^{67}$ Nor will the plaintiff usually be able to avoid the disability by assigning its claim to a party otherwise capable of bringing suit. ${ }^{68}$ Thus, in these cases, the corporation-or

60 See Note, 25 Colum. L. REv. 806, 806-11 (1925). (1908).

61 See, e.g., United Shoe Mach. Co. v. Ramlose, 210 Mo. 631, 109 S.W. 567

62 Mo. ANn. Stat. $\$ 351.635$ (1952). This statute was designed to emulate that of Illinois, which, however, contained a supplemental provision validating contracts. IIL. ANN. STAT. ch. 32, \$157.125 (Smith-Hurd 1954).

63 Hunter Packing Co. v. Trinity Universal Ins. Co., 98 F. Supp. 215 (E.D. III. 1948) (applying Missouri law).

64 See, e.g., Jerrold-Stephens Co. v. Gustaveson, Inc., 138 F. Supp. 11 (W.D. Mo. 1956) (dictum).

65 Salitan v. Carter, Ealey \& Dinwiddie, 332 S.W.2d 11 (Mo. Ct. App. 1960).

66 E.g., Big Four Mills, Ltd. v. Commercial Credit Co., 307 Ky. 612, 211 S.W.2d

831 (1948) ; G. Ober \& Sons v. Katzenstein, 160 N.C. 439, 76 S.E. 476 (1912); Toledo Tie \& Lumber Co. v. Thomas, 33 W. Va. 566, 11 S.E. 37 (1890). Many courts have reached the opposite conclusion. See 17 Fletcher, PrIVate Corporatrons $\$ 8506$, at 682 (rev. vol. 1960 ).

67 The burden of the injustice is no longer a matter for the courts. Van Schuyver Co. v. Breedman, 225 Fed. 1023 (9th Cir. 1915); Plibrico Jointless Firebrick Co. v. Waltham Bleachery \& Dye Works, 274 Mass. 281, 174 N.E. 487 (1931). It is sometimes said that the contract is unimpaired but the remedy is witheld. Weber $v$. Pend D'Oreille Mining \& Reduction Co., 35 Idaho 1, 203 Pac. 891 (1921). This formulation does not indicate what would happen in a local suit for restitution or in a suit on the contract in another jurisdiction, assuming defendant could be served.

68 The assignee will be treated in the same manner as the corporate assignor. Thus, if the defense of noncompliance would bar a suit by the corporation, the 
whoever asserts its claim-will be out of court unless the technical noncompliance was so insignificant that the corporation may be considered to have complied "substantially." 69

Notwithstanding statutes making contracts "void" or "unenforceable," a corporate plaintiff often can withstand a motion to dismiss by averring that the transaction or contract was out-of-state ${ }^{70}$ or that the suit is not

assignee's suit will be dismissed. Seattle Merchants' Ass'n v. Larson, 6 Alaska 264 (D.C. 1920) ; Republic Power \& Serv. Co. v. Gus Blass Co., 165 Ark. 163, 263 S.W. 785 (1924); Dean v. Caldwell, 141 Ark. 38, 216 S.W. 31 (1919); Viking Equip. Co. v. Central Hotel Co., 230 Mo. App. 304, 91 S.W.2d 94 (1936). But if the defense is merely one in abatement, subsequent compliance by the assignor will enable the assignee to maintain the suit. See Lewis v. Club Realty Co., 264 Mass. 588, 163 N.E. 172 (1928); Kraft v. Hoppe, 152 Minn. 143, 188 N.W. 162 (1922). The possibility of rehabilitation sometimes obtains even where the assignee itself is an undomesticated foreign corporation which is doing local business illegally. See, e.g., Fla. STat. ANN. §613.04 (1956); ILL. AnN. STAT. ch. 32, §157.125 (Smith-Hurd 1954); Minn. Stat. ANN. $\$ 303.20$ (1947). The failure to use the statute to secure compliance by both assignor and assignee is probably explicable by the fact that a potential assignee whose own local standing is uncertain will not ordinarily take claims of doubtful enforceability.

The relaxation of these rules in the area of negotiable instruments, where there is a countervailing policy to foster the circulation of commercial paper, is discussed in 17 Fietcher, PRIVATE CoRporations $\$ 8526$ (rev. vol. 1960).

The position of assignees, trustees, and receivers of dissolved or insolvent foreign corporations is unsettled. The predominant view is that the receiver will be barred from suit if the corporation would have been. Wiestling v. Marthim, 1 Ind. App. 217, 27 N.E. 576 (1891); Frank v. Broadway Tire Exch. Co., 42 R.I. 27, 105 Ati. 177 (1918); see Lowenmeyer v. National Lumber Co., 71 Ind. App. 458, 125 N.E. 67 (1919) (dictum). Contra, VT. STAT. ANN. tit. 11, \$764 (1958) (as to domestic receivers), Underhill v. Rutland R.R., 90 Vt. 462, 98 Atl. 1017 (1916). The same result has obtained where the plaintiff was trustee in bankruptcy of a foreign corporation. Fleming v. J. G. McCrory Co., 114 W. Va. 439, 174 S.E. 325 (1933). Contra, Okin v. A. D. Gosman, Inc. (N.J. Super. Ct. Oct. 25, 1961), in 84 N.J.L.J. 570 (1961). These cases suggest that it makes no difference that the corporation might have cured the defect but for dissolution, if in fact it had not done so before the receiver or trustee took over. Contra, Rubin v. Kapell, 105 So. 2d 28 (Fla. Dist. Ct. App. 1958) (dictum). For a recent relaxation of this dogma, where there was evidently no attempt being made to evade the statute by assignment, see Technical Tape Corp. v. Slusher, 358 P.2d 304 (Wash. 1961), in which the assignee was the parent corporation of a recently dissolved, undomesticated subsidiary; the assignee qualified during the course of the litigation. See also ALASKA COMP. LAwS ANN. tit. 36, $\$ 36-2 A-159$ (Supp. 1958), which allows suit by the assignee when a corporation "has acquired all or substantially all of [assignor's] assets." As to the "curability" of defects generally, see pp. 266-69 infra.

69 "Substantial" compliance has been found for these purposes where a previously domesticated corporation failed to repeat the necessary acts of compliance under a new domestication statute and suit was brought on a transaction antedating the new statute, Industrial Bldg. \& Loan Ass'n v. Meyers-Abel Co., 12 Ariz. 48, 95 Pac. 115 (1908), where the corporation sued under a name which was slightly different from that under which it was domesticated, Indian Ref. Co. v. Royal Oil Co., 102 Cal. App. 710, 283 Pac. 856 (Dist. Ct. App. 1929), and where the plaintiff corporation had complied with all domestication requirements save that it maintain a local stock transfer office, Claude Neon Fed. Co. v. Four Fundred Club, 16 Ia. App. 651, 134 So. 445 (1931) (alternative holding). But cf. Tarr v. Western Loan \& Sav. Co., 15 Idaho 741, 99 Pac. 1049 (1909) (no substantial compliance where charter not filed with county recorder). Decisions such as these should not prevent the state from subsequently requiring full compliance, recovering penalties, or barring further local activity, for the substantiality of compliance may properly depend on the purpose for which noncompliance is invoked.

70 The distinction pointed out earlier between statutes which close the courts' doors for any purpose and those which do so only for controversies arising from intrastate transactions, see text accompanying notes 50-51 supra, is important in these situations. 
one on or under the contract. The latter plea has little application beyond the fictional intricacies of quasi-contract, ${ }^{71}$ but the former involves subtle principles of conflict of laws. The court must decide the case in such a way as not to give domestication statutes extraterritorial effect. ${ }^{72}$ Of course, a contract may have several significant stages which can be split among two or more states, such as the places of negotiation, execution, performance, passing of title, and payment. Where less than all of the operative acts have been done or are agreed to be done in the forum state, the conflicts problem can be immense; but in practice the courts have not been greatly concerned with the complexities. More often than not their first step has been to apply the conflicts rule that the law governing shall be that of the place of the "making" of the contract, 73 the "making" in turn to depend upon where the last act to give the contract binding effect was performed.74 If that act occurred outside the forum state, the domestication law of the forum does not govern the transaction. In no case has there been inquiry into the "whole" law-including the law of the conflict of laws-of the place where the contract was "made," not even in cases in which the last act of contracting was the only contact with that place and the court might properly suspect that the making of the contract was carefully contrived so as to evade the local domestication statute. ${ }^{75}$

71 See Evyan Perfumes, Inc. v. Hamilton, 20 Misc. 2d 950, 195 N.Y.S.2d 869 (Sup. Ct. 1959) (assumpsit on common count, raising implied contract, not a "contract" action) ; cf. Knight Prods., Inc. v. Donnen-Fuel Co., 20 N.Y.S.2d 135 (Sup. Ct. 1940) (action for an accounting is a suit on a "contract").

72 E.g., Allen v. Alleghany Co., 196 U.S. 458 (1905); Hyde v. Goodnow, 3 N.Y. 266 (1850); New England Road Mach. Co. v. Calkins, 121 Vt. 118, 149 A.2d 734 (1959). A different result can obtain if the contract was "void" in the place of making, in which case no court is apt to enforce it.

73 This is the usual conflicts of law rule governing contracts, and there can be no objection to the forum making this initial characterization according to its own law. Other possible choices are the law of the state where the "essential" contacts are grouped and the law of the state where performance is contemplated. While reason might commend either of these alternatives in some situations, courts have seldom done so. See text accompanying note 83 infra. See generally GoodrICE, CONFLICT OF LAWS $\$ 110$ (3d ed. 1949).

74 See Goodrich, op. cit. supra note $73, \S 107$. This choice of law is made on the basis of the internal law of the forum state. The last act is usually the offeree's signature. See Transradio Press Serv., Inc. v. Whitmore, 47 N.M. 95, 137 P.2d 309 (1943); Alexander Film Co. v. Pierce, 46 N.M. 110, 121 P.2d 940 (1942); Thorner v.' Selective Cam Transmission Co., 4 Cal. Rptr. 409 (Ct. App. 1960). But see Republic Acceptance Corp. v. Bennett, 220 Mich. 249, 257, 189 N.W. 901, 904 (1922), where the controlling last act was the delivery of plaintiff's check in payment for the goods bought. In the absence of a showing as to where the contract was made, a motion to dismiss has been denied because the court generously considered itself bound to presume "that the contract was not made within this state and that the corporation is not doing business here." National Merchandising Corp. v. Powers, 8 Misc. 2d 881, 168 N.Y.S.2d 507 (Sup. Ct. 1957).

75 In Alexander Film Co. v. Pierce, 46 N.M. 110, 121 P.2d 940 (1942), the foreign corporation would not be bound on any contract until it had been signed at the home office. Every other significant contact took place in the state where it failed to domesticate-solicitation, negotiation, performance. Application of the last-act-tomake-it-binding test absolved plaintiff of the local statutory infirmity. See Hayes, Iowa Corporations \& Partnerships: 1942-1952, 38 IowA L. REv. 462, 489 (1953). The uniformity with which courts use the "place of making" and the "last act" as controlling factors may account for the common practice of requiring home office acceptance of all out-of-state contracts. A small and distinct portion of this problem 
Plaintiff's right to maintain a contract suit may remain unimpaired if the defendant can be found to have "waived" plaintiff's noncompliance ; 76 this possibility obtains primarily in those jurisdictions whose statutes do not bar plaintiff's suit but merely withhold a remedy until compliance is completed. In such a case, it is reasoned that since defendant never had a defense on the merits and could only abate the suit until plaintiff complied, the court may overlook the technicality of requiring compliance if the defense has not been raised at an early stage. This result appears equitable as between the parties-it may make sense to penalize the defendant for neglect where the court's resources have been taxed by a trial-but it entirely overlooks the state's interest. By denying defendant the right to stave off final judgment at least until plaintiff complies, the court permits the corporate offender to obtain its judgment without complying-in direct contravention of the statute. The state may find this particularly objectionable if it becomes the feeling of defendants generally that it is not to their advantage to plead a merely dilatory defense ${ }^{77}$ and foreign corporations cease to consider the disability a spur to compliance.

\section{B. Protection of Property and Related Rights}

Notwithstanding statutes barring the maintenance of an action for failure to domesticate, there are procedures-of varying degrees of efficacy -by which a foreign corporation can use local courts to protect its property within the state.

Among the methods for protection of personalty which have met with some success are replevin ${ }^{78}$ - sometimes even though the wrongful retention of the property arose from a contract which in that state would be wholly void ${ }^{79}$ - , trover, ${ }^{80}$ and conversion. ${ }^{81}$ The rationale usually expressed is a distinction between contract and tort.

is dealt with by statutes declaring undomesticated corporations ineligible to enter into any contract for certain state construction which is required to be let by sealed bid. E.g., Neb. Laws 1959, ch. 77, §1, at 316.

76 Reed \& Co. v. Harshall, 12 Cal. App. 697, 108 Pac. 719 (Dist. Ct. App. 1910); Gallafent v. Tucker, 48 Idaho 240, 281 Pac. 375 (1929); Outdoor Elec. Advertising, Inc. v. Saurage, 207 La. 344, 21 So. 2d 375 (1945) ; cf. Peter \& Burghard Stone Co. v. Carper, 96 Ind. App. 554, 172 N.E. 319 (1930). Where contracts made before compliance are "void," no waiver is possible. National Union Indem. Co. v. Bruce Bros., 44 Ariz. 454, 38 P.2d 648 (1934).

77 See notes 162-63 infra and accompanying text.

78 See Rex Beach Pictures Co. v. Harry I. Garson Prods., 209 Mich. 692, 177 N.W. 254 (1920); United Shoe Mach. Co. v. Ramlose, 231 Mo. 508, 132 S.W. 1133 (1910). But see Case v. Mills Novelty Co., 187 Miss. 673, 193 So. 625 (1940); cf. Cable Piano Co. v. Estes, 206 Ala. 95, 89 So. 372 (1921) (detinue).

79 United Shoe Mach. Co. v. Ramlose, supra note 78; Mojonnier Bros. v. Detroit Milling Co., 233 Mich. 312, 206 N.W. 525 (1925) (dictum).

80 Dominion Fertilizer Co. v. White, 115 Me. 1, 96 Atl. 1069 (1916) (construing "no action" statute to bar only contract action); Farrand Co. v. Walker, 169 Mo. App. 602, 155 S.W. 68 (1913) (though contract with agent void, corporation may bring trover); MacLeod v. G. P. Putnam's Sons, 24 R.I. 500, 53 Atl. 867 (1902) (judgment gained in trover suit not itself a "contract" so as to be barred).

81 Lu-Mi-Nus Signs Co. v. Regent Theatre Co., 250 Mich. 535, 231 N.W. 128 (1930); National Match Co. v. Empire Storage \& Ice Co., 227 Mo. App. 1115, 58 
Courts have permitted foreign corporations to protect their real property within the state by ejectment and recovery of possession. ${ }^{82}$ On the other hand, suits to foreclose mortgages have not been uniformly successful. The Supreme Court has allowed a state to deny foreclosure of a mortgage on local land by an incompletely domesticated corporation, even though all the contacts of the note obligation which the mortgage secured were made in another state. ${ }^{83}$ But foreclosure may be successful if the corporation can show compliance by its predecessor trustee, ${ }^{84}$ if the state allows subsequent compliance to cure disability and such compliance is forthcoming before final judgment, ${ }^{85}$ or, of course, if the foreign corporation is held not to have engaged in intrastate business. ${ }^{80}$

The question of "waiver" of the defense of noncompliance has not been squarely presented to the courts in mortgage foreclosure cases as it has in the context of contracts. However, the fact of noncompliance has been raised and rejected in two cases. One arose on a petition to vacate a prior judgment; ${ }^{87}$ the other was a suit to quiet title against an execution sale purchaser. ${ }^{88}$ In both there was a failure to plead noncompliance at the time of foreclosure, an active defense on other grounds, and a final judgment decreeing foreclosure on behalf of the foreign corporation. These cases are obviously much stronger for penalizing the defendant's delay, even considering the state's interest in securing compliance, than such as did so in the contract areas, for here the postjudgment assertion of noncompliance is a collateral attack on that judgment which may affect the rights of third parties and disrupt orderly judicial procedure. The denial of the bar of noncompliance because of a prolonged delay also subserves the state's policy, at least where precompliance contracts are void, by urging the defendant to diligence in unearthing plaintiff's unauthorized conduct. However, this consideration is not peculiar to foreclosure cases.

S.W.2d 797, cert. denied, 290 U.S. 668 (1933). Where plaintiff pleads a cause of action on a contract and one for conversion, in the alternative, summary dismissal has been denied. Arkansas Airmotive Div. of Currey Aerial Sprayers, Inc. v. Arkansas Aviation Sales, Inc., 335 S.W.2d 813 (Ark. 1960).

82 Sayers \& Miuir Serv. Station v. Indian Ref. Co., $266 \mathrm{Ky} .779,100$ S.W.2d 687 (1936); Darling Shops Delaware Corp. v. Gelmart, Inc., 72 N.Y.S.2d 26 (Sup. Ct. 1947). Analogously, it has been held that a foreign corporation can sue for possession of severed realty, D. M. Ferry \& Co. v. Smith, 36 Idaho 67, 209 Pac. 1066 (1922), and to protect realty against trespass, Indian River Mfg. Co. v. Wooten, 55 Fla. 745, 46 So. 185 (1908).

83 Chattanooga Nat'1 Bldg. \& Loan Ass'n v. Denson, 189 U.S. 408 (1903).

84 American Nat1 Bank \& Trust Co. v. Edith Rockefeller McCormick Trust, 223 Wis. 590,270 N.W. 345 (1937).

85 Burton v. Oliver Farm Equip. Sales Co., 121 Fla. 148, 163 So. 468 (1935) (domestication during trial); Hogue v. D. N. Morrison Constr. Co., 115 Fla. 293, 156 So. 377 (1937). Contra, Tarr v. Western Loan \& Sav. Co., 15 Idaho 741, 99 Pac. 1049 (1909). Foreclosure by advertisement has been allowed to proceed in the face of a statute prohibiting the maintenance of an "action." Flakne v. Metropolitan Life Ins. Co., 198 Minn. 465, 270 N.W. 566 (1936).

${ }^{86}$ E.g., Martin v. Bankers' Trust Co., 18 Ariz. 55, 156 Pac. 87 (1916) (foreclosure); see Family Budget Plan, Inc. v. Ede, 5 Bucks 121 (Pa. C.P. 1955).

87 Steele v. The Maccabees, 175 Okla. 471, 53 P.2d 232 (1936).

88 Apache Land \& Cattle Co. v. Franklin Life Ins. Co., 145 F.2d 964 (9th Cir. 1944) (applying Arizona law which declared acts void). 
Analogous to the protection-of-property suits are those in which a foreign corporation seeks to enjoin the use or registration of a deceptively similar corporate name or seeks to invoke a local fair trade law in order to enforce a resale price maintenance policy. It is to be observed, however, that no effort has been made by the courts to analogize to "protection of property" when confronted with these situations. ${ }^{89}$ Although it has been held that a foreign corporation which has done no local business-and thus is not subject to domestication requirements or to disabilities for failure to domesticate-cannot enjoin a local corporation from using a deceptively similar name, since it would be inimical to the public policy of the state to allow an attack on a corporate name approved by the state, ${ }^{90}$ the New York courts have allowed an injunction both when the foreign corporation was not doing intrastate business ${ }^{91}$ and when it was ${ }^{92}$ - the latter despite the fact that plaintiff's case would require affirmative proof of its unauthorized intrastate conduct. It would seem to be clearly to the state's advantage for a court to allow such actions by foreign corporations; local citizens will benefit, for when a corporate name is "deceptively similar," it is they who may be duped and injured. Therefore, the states should be hospitable to these suits, notwithstanding their interest in regulating foreign corporations.

89 It is arguable that a corporation should be able to protect the "property" which it has in its name or its goodwill as readily as its physical possessions, no matter how those interests are labeled for other purposes. Considering the purposes for which domestication statutes are enacted, a failure "to strictly comply with the statutes . . . does not so shock the conscience of the chancellor as to make it a prey to all evilly disposed persons." Northwest Ready Roofing Co. v. Antes, 117 Neb. 121, 124, 219 N.W. 848, 850 (1928). The Fifth Circuit came close to a protection-of-plaintiff's-property analysis when it allowed suit for an injunction in Scalise v. National Util. Serv., Inc., 120 F.2d 938 (5th Cir. 1941). In that case, plaintiff, an unregistered foreign corporation, filed suit to enjoin defendant from using its name. When it was discovered that plaintiff was not registered, the action was abated for the specific purpose of allowing it to register. Defendant, however, which was also unregistered, succeeded in domesticating before plaintiff had an opportunity to do so, hoping thereby to foreclose its action. The court nevertheless enjoined defendant's use of plaintiff's name.

80 Hazelton Boiler Co. v. Hazelton Tripod Boiler Co., 142 I1l. 494, 30 N.E. 339 (1892). Cf. Investors Syndicate of America, Inc. v. Hughes, 378 Ill. 413, 38 N.E.2d 754 (1942). In General Indus. Co. v. 20 Wacker Drive Bldg. Corp., 156 F.2d 474 (7th Cir.), cert. denied, 329 U.S. 792 (1946), an injunction was granted. The distinction was taken between what the plaintiff could do in state and federal courts to protect its name. Some of the cases relied upon were pre-Erie. If Illinois law governed the plaintiff's rights, as the court indicated, it is hard to see how the federal court could avoid the "public policy" expressed in the Illinois decisions. See note 17 supra and accompanying text.

91 National Tool Salvage Co. v. National Tool Salvage Indus., Inc., 186 Misc. 833, 60 N.Y.S.2d 308 (Sup. Ct. 1946).

92 Dunkin' Donuts of America, Inc. v. Dunkin Donuts, Inc., 176 N.Y.S.2d 915 (Sup. Ct. 1958), aff'd, 8 App. Div. 2d 228, 188 N.Y.S.2d 132 (1959). The statute invoked was one barring suits on locally made contracts, and the court found that there was no contractual relationship between the parties. In addition, the court was reluctant to add disabilities not specifically legislated-a consistent policy of the New York courts. See Pennsylvania Publications, Inc. v. Senft, 280 App. Div. 918, 116 N.Y.S.2d 5 (1952) (per curiam) (common-law fraud suit not barred); Evyan Perfumes, Inc. v. Hamilton, 20 Misc. 2d 950, 195 N.Y.S.2d 869 (Sup. Ct. 1959) (assumpsit on common count, raising implied contract, not a "contract" action). In Home Insulation Co. v. Home \& Bldg. Insulation Co., 175 Okla. 428, 52 P.2d 1065 (1936), suit for an injunction against the use of a deceptively similar name was allowed, but no inquiry was made as to whether the corporation was engaged in intrastate business. 
Several recent decisions have considered whether an undomesticated foreign corporation can take advantage of a local fair trade statute by enjoining sales below the fixed price. They clearly acknowledge that mere resort to local courts for this purpose is not a doing of business sufficient to subject the corporation to domestication requirements and incapacitate it from suing before compliance.93 However, if other acts of the corporation amount to intrastate business, the corporation may be prevented from involking the fair trade statute, even though the business which it wants ultimately to defend is interstate. ${ }^{94}$ Since the power to enforce a fair trade policy derives solely from state statutes, ${ }^{95}$ it is only fair, as the New Jersey court observed in Eli Lilly \& Co. v. Sav-On Drugs, Inc. ${ }^{96}$ to require a foreign corporation "which seeks to take advantage of a cause of action given it by one of our laws, to comply with the provisions of the other as a condition to taking advantage of the other statute." 97

Eli Lilly illustrates the unfortunate extent to which small factual variations may affect the results of cases in this area. In Remington Arms Co. v. Lechmere Tire \& Sales Co., ${ }^{98}$ where plaintiff corporation was engaged in only slightly less local activity ${ }^{99}$ than that described in Lilly, ${ }^{100}$ the Massachusetts court held that the corporation was engaged solely in interstate business and could invoke the local fair trade act as a necessary incident to that business. The decision was clearly based on a construction of the local domestication statute, not on the judges' interpretation of the constitutional limits of state regulation of foreign corporations. ${ }^{101}$ The court conceded that the precedents on which it relied might be a bit old fashioned in the light of more recent Supreme Court cases under the commerce clause, but it expressly dismissed those cases as irrelevant to the interpretation of the state statute. ${ }^{102}$ Nevertheless, the New Jersey court,

93 Remington Arms Co. v. Lechmere Tire \& Sales Co., 339 Mass. 131, 158 N.E.2d 134 (1959); Weco Prods. Co. v. G.E.M., Inc., 2 CCH Corp. L. GumE II 9773 (Minn. Dist. Ct. March 1, 1960) ; United States Time Corp. v. Grand Union Co., 64 N.J. Super. 39, 165 A.2d 310 (Ch. 1960).

${ }^{94}$ See Eli Lilly \& Co. v. Sav-On Drugs, Inc., 57 N.J. Super. 291, 154 A.2d 650 (Ch. 1959), aff'd, 31 N.J. 591, 158 A.2d 528, aff'd, 366 U.S. 276 (1961). (1953).

95 General Elec. Co. v. Packard Bamberger \& Co., 14 N.J. 209, 102 A.2d 18

${ }^{96} 57$ N.J. Super. 291, 154 A.2d 650 (Ch. 1959), aff'd, 31 N.J. 591, 158 A.2d 528, $a f f^{\prime} d, 366$ U.S. 276 (1961).

$97 \mathrm{Id}$. at $304,154 \mathrm{~A} .2 \mathrm{~d}$ at 657 .

88339 Mass. 131, 158 N.E.2d 134 (1959).

99 Remington's activity in Massachusetts consisted of maintaining a local office with a full-time employee and bank account, employing solicitor-salesmen, displaying sample guns, giving chevrons to gun clubs, employing field agents and shoppers to detect violations of local fair trade contracts, and suing occasionally to enforce resale price maintenance. Id. at 133-35, 158 N.E.2d at 136-37.

100 Lilly's activity in New Jersey consisted of maintaining a local office with two permanent employees and eighteen "detailmen," whose salaries were paid by the home office and whose function was to visit retail pharmacists, physicians, and hospitals in order to promote plaintiff's products. The detailmen occasionally accepted retailers' orders for transmittal to a wholesaler. 57 N.J. Super. at 298-99, 154 A.2d at 654.

101 See 335 Mass. at 136-37, 158 N.E.2d at 138.

102 Ibid. 
when it came to dispose of Remington in order to decide Lilly, rejected the Massachusetts case on the ground that it might have gone the other way had counsel argued the obsolescence of the older cases. ${ }^{103}$

The apparent lack of predictability which these two cases suggest is especially unfortunate in an area where the substantive law may have the effect of drawing large corporations into local litigation to enforce rights given to them under local law, only to be confronted by the challenge that previous local promotional activities add up to local doing of business. And it is difficult to find possible patterns for the future by looking to the policy of the fair trade laws themselves. To the extent that they are intended to protect local retailers against loss-leader competition and local consumers against fraudulent practices which might be introduced to promote that competition, ${ }^{104}$ the courts might well be motivated to place as few obstacles as possible in the way of a national producer trying to enforce these laws. The motivation might be especially strong if the defendant who invokes the domestication statute has apparently not been the victim of any of the specific evils intended to be prevented by the statute. Balancing this motivation is the rationale expressed by the New Jersey court: insofar as the fair trade law is designed to confer an economic advantage upon the plaintiff-by protecting its good will as represented by its brand name ${ }^{105}$ the state can rightly insist that the corporation be held to rigorous compliance with state laws before it may enforce that advantage. ${ }^{106}$

\section{Arbitration}

New York has faced, virtually alone, the problem of whether an undomesticated foreign corporation can use local courts to compel arbitration under a locally made contract. Its domestication statute provides that no "action" can be maintained by such corporation. ${ }^{107}$ The first construction of the statute on this point was to the effect that arbitration would be barred since the term "action" encompasses all legal remedies which require invocation of the jurisdiction of the courts. ${ }^{108}$ But in In the Matter of Tugee Laces, Inc. ${ }^{109}$ the New York Court of Appeals accepted the contrary view, classing arbitration as a "special proceeding" and holding that service of notice to arbitrate is not the institution of an "action" within the meaning of the domestication statute. ${ }^{110}$ This conclusion may have been carried another step by the decision of a lower New York court allowing con-

10357 N.J. Super. at 301, 158 A.2d at 656.

104 See Fulda, Resale Price Maintenance, 21 U. CHI. L. REv. 175, 180-84 (1954). 105 See $i d$. at 18486.

106 See note 97 supra and accompanying text.

107 N.Y. GEN. CoRP. LAW $\$ 218$.

108 In the Matter of Vanguard Films, Inc., 188 Misc. 796, 67 N.Y.S.2d 893 (Sup. Ct. 1947).

109297 N.Y. 914, 79 N.E.2d 744 (1948).

110 This decision controlled an unwilling court in Avalon Fabrics, Inc. v. Raymill Fabric Corp., 96 N.Y.S.2d 50 (Sup. Ct. 1950). 
firmation and enforcement of an arbitration award involving two undomesticated foreign corporations.111 Whether this position will be extended to the enforcement of an award against a domestic defendant is problematical. ${ }^{112}$

The Tugee Laces decision is contrary to the policy of the disability provision of the domestication statute, which is to apply sufficient pressure to an offending corporation to force it to domesticate. If the plaintiff corporation should prevail in the arbitration, it may well have achieved in effect precisely what it was seeking when it made its local contract arbitrable under the local statute, for the defendant may be inclined to abide by the award and avoid the further expense and trouble of defending a motion to confirm or prosecuting a motion to vacate. However, assuming that the court of appeals was correct in allowing the use of court processes to compel arbitration, it is difficult to see how any further obstacle can then be placed in the way of the plaintiff's carrying the arbitration all the way to confirmation and judgment. The quality of arbitration as a "special proceeding" hardly permits anything but a formalistic distinction to be made between compelling arbitration and enforcing an award. It would be a waste of the court's and the parties' time for the court to compel arbitration if, subsequently, it would be unwilling to enforce an award. ${ }^{113}$

\section{Suits Against Unfaithful Agents}

Occasionally a foreign corporation will have to resort to the courts of a state in which it has not domesticated in order to vindicate its rights against one of its own employees or agents. If the employee has withheld funds collected on behalf of the corporation, the corporation's ability to recover them may depend on the familiar issue-whether it has done local business. ${ }^{114}$ The disability is said to express "the broad and controlling rights of the public" which override "the propriety and policy of a rule of private law." I15 Some courts, however, have allowed relief on the ground

111 In the Matter of Terminal Auxiliar Maritima, S.A., 11 Misc. 2d 697, 178 N.Y.S.2d 298 (Sup. Ct. 1957) ; cf. Temple v. Riverland Co., 228 S.W. 605 (Tex. Civ. App. 1921) (entry of judgment after statutory arbitration is ministerial, involving no judicial function, hence not an "action" within prohibition of domestication statute).

112 A1though the court employs the "special proceeding" dialectic found in Tugee Laces, its holding might be able to be sustained under N.Y. GEN. CoRP. LAW $\$ 225$, permitting certain actions by undomesticated foreign corporations where the defendant is also a foreign corporation. The opinion does not state sufficient facts to determine whether this is true.

113 Cf. 110 U. PA. L. REv. 113, 118 (1961).

114 Compare S. Gumpert Co. v. Hernreich, 199 Ark. 376, 134 S.W.2d 568 (1939), with Thomas Mfg. Co. v. Knapp, 101 Minn. 432, 112 N.W. 989 (1907). See also Country Club Soda Co. v. Weinberg, 3 Conn. Supp. 237 (C.P. 1935) (employee enjoined from soliciting plaintiff's customers on behalf of a competitor).

115 Thomas Mfg. Co. v. Knapp, supra note 114, at 438, 112 N.W. at 992 ; accord, J. R. Watkins Medical Co. v. Williams, 124 Ark. 539, 187 S.W. 653 (1916); see Note, 3 Texas L. Rev. 183, 188 (1925). 
either that the employee is "estopped" to deny plaintiff's right to the funds or that a contrary result would sanction employee dishonesty. ${ }^{116}$

Efforts to harmonize these polar policies are inhibited by the courts' retreat behind "estoppel" and "public rights." While it is true that the state has seen fit to disable the corporation for its misconduct, it is equally true that the agent should be stripped of illicit gains. The fact that one state policy is expressed through legislative enactment and the other is embodied in the common law should have no significance in circumstances where the purpose of the common-law rule can be well served or seriously. injured, depending on the outcome of the case, while the purpose underlying the statute will not be much affected by either result. If the corporation is not allowed to sue, the statutory policy is arguably served by a promotion of an indirect deterrent to noncompliance, but the common-law policy is crippled by removing one of the most effective deterrents to embezzlement-stripping the embezzler of his ill-gotten gains. ${ }^{117}$ On the other hand, if the corporation is allowed to sue, the common-law policy is promoted and, since the defendant is not among the class intended to be directly protected by the domestication law, the statutory policy is only slightly disserved. Hence, the corporation should be allowed to sue in this kind of case. ${ }^{118}$

\section{E. Capacity to Defend Lazesuits}

A high degree of uniformity obtains regarding the ability of undomesticated foreign corporations to defend all varieties of suits. ${ }^{119}$ The right to do so is held to apply with equal force to substantive and pro-

116 United States Express Co. v. Lucas, 36 Ind. 361 (1871); cf. Hovey's Estate, $198 \mathrm{~Pa}$. 385, 48 Atl. 311 (1901) (recovery of corporate funds from estate of deceased agent).

117 Of course, the defendant is always subject to criminal prosecution, regardless of the limits on the corporation's right to recover. E.g., Barr v. State, 10 Ala. App. 111, 65 So. 197 (1914).

118 Other types of actions against agents or employees which have been allowed, evidently without destroying the state's domestication policy, are trover under circumstances in which the contract with the agent-defendant was void due to the corporation's failure to comply, Farrand Co. v. Walker, 169 Mo. App. 602, 155 S.W. 68 (1913), and a suit for an injunction against the disclosure of trade secrets, JerroldStephens Co. v. Gustaveson, Inc., 138 F. Supp. 11 (W.D. Mo. 1956).

119 See, e.g., Haberman v. Equitable Life Assur. Soc'y, 224 F.2d 401, modified, 225 F.2d 837 (5th Cir. 1955), cert. denied, 350 U.S. 948 (1956) (rescission); Frantz v. McBee Co., 77 So. 2d 796 (Fla. 1955) (tort) ; Brecht v. Bur-Ne Co., 91 Fla. 345, 108 So. 173 (1926) (protection of property); Rowley v. Bird Island Trapping Co., 202 Ia. 273, 11 So. $2 d 553$ (1942) (assignment); Gill v. S.H.B. Corp., 322 Mich. 700,34 N.W.2d 526 (1948) (contract); Newcomb v. Blakenship, 256 S.W.2d 700 (Tex. Civ. App. 1953); John C. Cutler Ass'n v. DeJay Stores, 3 Utah 2d 107, 279 P.2d 700 (1955). Oddly enough, in a state whose statute says nothing about the right to defend in the event of failure to appoint a local agent for service of process and does not require a foreign corporation to appoint such an agent until its articles are filed, such a corporation has been allowed to defend while in total violation of the law but not if it has taken the first and not the second step of compliance. See Winston v. Idaho Hardwood Co., 23 Cal. App. 211, 137 Pac. 601 (Dist. Ct. App. 1913). 
cedural ${ }^{120}$ defenses. In many jurisdictions the right to defend is now specifically preserved by statute; ${ }^{121}$ in a few, however, noncompliance statutorily precludes a foreign corporation from the benefits of local laws, especially the statute of limitations. ${ }^{122}$

Counterclaim may be one important part of a defendant's position and a foreign corporation will ordinarily be permitted to assert a counterclaim, ${ }^{123}$ although compliance at that time may be necessary. ${ }^{124}$ Understandably, this right will usually be denied where the counterclaim is based on an intrastate transaction the vindication of which would otherwise be barred by the relevant statute. ${ }^{125}$ The right may, of course, be statutorily withheld, ${ }^{128}$ but in a case where this was not done, even a discontinuance of plaintiff's suit was held not to convert defendant corporation into a "plaintiff" so as to require discontinuance of the counterclaim as well. ${ }^{\mathbf{1 2 7}}$ There appears to be no undue hardship on plaintiffs in allowing, within limits, the presentation of counterclaims, whereas their prohibition might permit claims to be presented with less than full disclosure of the probative facts, while simultaneously distorting the purpose behind the maintenanceof-suit disability. ${ }^{128}$

120 Steiner v. 20th Century-Fox Film Corp., 232 F.2d 190 (9th Cir. 1956) (statute of limitations); Taylor v. Navigazione Libera Triestina, 95 F.2d 907 (9th Cir. 1938) (same). A change of venue can always be requested by a foreign corporation. Mergenthaler Linotype Co. v. Herrmann, 211 S.W.2d 633 (Tex. Civ. App. 1948). Whether it will be granted will generally depend upon where defendant corporation carries on its intrastate business. Kentucky Straight Creek Coal Co. v. Commonwealth, $304 \mathrm{Ky} .247,200$ S.W.2d 470 (1947). But the privilege of change can be readily lost by defective pleading, Mergenthaler Linotype Co. v. Herrmann, supra; defective compliance, Noland Co. v. Laxton Constr. Co., 244 N.C. 50,92 S.E.2d 398 (1956); or defective partial compliance, Kane v. Universal Film Exchs., Inc., 32 Cal. App. 2d 365, 89 P.2d 693 (Dist. Ct. App. 1939) (no county place of business established).

121 See statutes cited note 52 supra.

122 Hawarr REv. LAws $\$ 174-10$ (1955) (benefits of Hawaiian law denied, particularly the statute of limitations); IDAHO CODE ANN. $\$ 30-509$ (1948) (statute of limitations denied for failure to comply); MD. ANN. CoDe art. 23, §93 (1957) (statute of limitations denied); NEv. REv. STAT. $\$ 80.220$ (1957) (statute of limitations suspended during noncompliance); UTAF CoDE ANN. \$16-8-3 (1953) (benefit of laws relating to corporations denied); Wrs. STAT. A.NN. $\$ 180.847$ (1957) (capacity to defend denied until compliance) ; see Black v. Vermont Marble Co., 1 Cal. App. 718, 82 Pac. 1060 (Dist. Ct. App. 1905).

123 Intra-Mar Shipping (Cuba) S.A. v. John S. Emery \& Co., 11 F.R.D. 284 (S.D.N.Y. 1951). In Smith v. Kincade, 232 F.2d 306 (5th Cir. 1956), the assertion of the counterclaim under FED. R. CTv. P. 13, was permitted despite a state prohibition against bringing or maintaining actions.

124 M. S. Cohn Gravel Co. v. Terry, 135 Okla. 275, 275 Pac. 1048 (1928).

125 Roberts v. Cat-Nak Mfg. Co., 216 I11. App. 245 (1919) (set-ofi relating to intrastate business); Rib Falls Lumber Co. v. Lesh \& Mathews Lumber Co., 144 Wis. 362, 129 N.W. 595 (1911) (counterclaim arising from wholly void contract). But see Smith v. Kincade, 232 F.2d 306 (5th Cir. 1956).

126 See UTA CODE ANN. §16-8-3 (1953).

127 Bellak v. Bon Specialty Co., 80 N.Y.S.2d 248 (Sup. Ct. 1948).

$128 \mathrm{~A}$ minor but analogous area concerns the assertion of cross-claims. The few cases discussing this problem provide no basis for the formulation of a rule. See Tarr v. Western Loan \& Sav. Co., 15 Idaho 741, 99 Pac. 1049 (1909) (permitted) ; Hightower Petroleum Corp. v. Story, 236 S.W.2d 679 (Tex. Civ. App. 1951) (refused). In Flakne v. Metropolitan Life Ins. Co., 198 Minn. 465, 471, 270 N.W. 566, 569 (1936), the court stated that "by bringing [defendant] . . into court, the appellants are estopped from claiming that defendant has no right to be in court." 
Foreign corporations have not been hindered in their use of substantive defenses. ${ }^{129}$ But neither they, nor those in privity with them, ${ }^{130}$ have been permitted to raise their own noncompliance as a defense. ${ }^{131}$ A foreign corporation has even been denied the right to defend with its noncompliance a suit brought by its president, although, in his official capacity, he may have been solely responsible for the fact that it had not been domesticated. ${ }^{132}$

\section{Personal Civil and Criminal Liability of Officers AND SHAREHOLDERS}

A final technique for securing compliance with domestication laws is to subject officers, agents, or shareholders to criminal penalties or personal civil liability for local corporate acts. ${ }^{133}$ There is little case law embellishing the statutes that employ criminal sanctions; apparently they have seldom been invoked to secure compliance. Personal civil liability has been somewhat more frequently resorted to-at least it was during the early part of this century.

Short of attempts to extend legislative jurisdiction to encompass nondomiciliaries who did not consent to the entry of the corporation of which they were shareholders into the forum state, ${ }^{134}$ few difficulties were en-

129 E.g., permitting evidence of full performance, see Haberman v. Equitable Life Assur. Soc'y, 224 F.2d 401, modified, 225 F.2d 837 (5th Cir. 1955), cert. denied, 350 U.S. 948 (1956) ; Sandia Dev. Corp. v. Allen, 86 Ariz. 40, 340 P.2d 193 (1959); Carolin Mfg. Corp. v. George S. May, Inc., 312 Mich. 487, 20 N.W.2d 283 (1945); McMillan v. Pawnee Petroleum Corp., 151 Okla. 4, 1 P.2d 775 (1931). (1909).

130 Kuennan v. United States Fid. \& Guar. Co., 159 Mich. 122, 123 N.W. 799

131 Davis v. Asano Bussan Co., 212 F.2d 558 (5th Cir. 1954) ; Cutting v. Bryan, 30 F.2d 754 (9th Cir.), cert. denied, 279 U.S. 860 (1929); Union Bank Note Co. v. Ajax Portland Cement Co., 155 Mo. App. 349, 137 S.W. 18 (1911). Nor can noncompliance be asserted to avoid validity of service of process. Wentling v. Popular Science Publishing Co., 176 F. Supp. 652 (M.D. Pa. 1959); Showen v. J. L. Owens Co., 159 Mich. 321, 122 N.W. 640 (1909) ; cf. Taylor v. Aldridge, 180 Miss. 635, 178 So. 331 (1938); Vogue Mfg. Co. v. Cadillac Hosiery Co., 83 Pa. D. \& C. 337 (C.P. 1952). The disability appears in statutory form in ALA. CoDE tit. 10, §21(89) (Supp. 1959).

132 Tucker v. Cave Springs Mining Corp., 139 Cal. App. 213, 33 P.2d 871 (Dist. Ct. App. 1934). The defendant corporation did defend on the merits at trial, but it urged, on appeal, that its noncompliance, for which plaintiff was allegedly responsible, deprived it of the necessity to defend against adverse litigation.

133 Criminal penalties: DeL. Code ANN. tit. 8, §349 (1953) (agent) ; ArA. Code tit. 10, \$21(94) (Supp. 1959) (servant); Orio REv. CoDE ANN. \$1703.30 (Page 1954) (officer); Iowa CODE ANN. \$494.13 (1949) (employee); CAL. CoRP. CODE $\$ 6803$ (any person). Severity of penalty: LA. Rev. Stat. ANN. \$12.205(c) (1951) ( $\$ 25-\$ 500$ fine) ; PA. STAT. ANN. tit. $15, \$ 2852-1014$ (1958) (up to 30 days in jail); Fla. Stat. ANN. \$613.11 (1956) (up to 6 mos. imprisonment); Ala. Code tit. 10, \$21 (94) (Supp. 1959) (up to 12 mos. imprisonment at hard labor); MoNT. REv. CODES ANN. \$15-1706 (1955) (offense classed as misdemeanor, penalties provided by general penalties section of criminal code).

Civil liability: IDAHo CODE ANN. $\$ 30-508$ (1948) (officers, agents, representatives) ; MASS. GEN. LAwS ANN. ch. 181, § 5 (1955) (officers, agents); UTAB CODE ANN. \$16-8-3 (1953) (agent); WYo. STAT. ANN. \$17-34 (1957) (officers, agents, and shareholders). (1934).

134 See Towle v. Beistle, 97 Ind. App. 241, 186 N.E. 344 (1933), 9 IND. L.J. 316 
countered by parties attempting to hold officers or associates personally liable for corporate obligations under local statutes expressly providing that remedy. ${ }^{135}$ And, even in the absence of such a statute, liability was successfully predicated on several common-law theories, the most common of which were that the persons transacting local business were liable as agents for a nonexistent corporate principal (none such having been authorized to do business in the forum state) ${ }^{136}$ and that the attempt to do business without qualification was equivalent to coming into the state as a partnership, without corporate immunity. ${ }^{137}$ In theory the "agency" approach seems narrower than the "partnership" approach, for the latter apparently permits even those who did not actually conduct the corporate affairs-including inactive associates ${ }^{138}$-to be reached. Practice, however, did not go as far as the possibilities of theory suggest. Under the auspices of "exceptions," nonliability for corporate obligations was accorded to nonresident, inactive members of the corporation, through rejection of the partnership theory, ${ }^{139}$ and to active members, through rejection of the agency theory. ${ }^{140}$ In some cases the courts interpreted other statutory provisions, such as those declaring contracts valid, as declaratory of a policy that corporate obligations were exactly that-corporate; in others the absence of provisions voiding contracts was said to demonstrate the exclusiveness of the specific penalties provided. ${ }^{141}$ Many of these complexities and circumventions might possibly have been avoided if the courts had found a rationale sui generis to foreign, noncompliant corporations, instead of borrowing from doctrines of agency and partnership law. But they did not, and thereby they failed to provide adequate basis for prediction. ${ }^{142}$

135 See, e.g., Keeler v. Union Trust Co., 84 Colo. 353, 270 Pac. 867 (1928) (recovery allowed against incorporator-officer-agents under statute requiring personal liability on contracts made for noncomplying foreign corporations). But cf. Herbert $H$. Pape, Inc. v. Finch, 102 Fla. 425, 136 So. 496, aff'd on rehearing, 102 Fla. 432, 136 So. 500 (1931), where recovery was barred against officer-shareholders for default on a foreign corporation's note given for the sale of land, the court distinguishing the mere purchase of property from other forms of doing business which might have imposed liabiilty.

${ }_{136}$ E.g., Joseph T. Ryerson \& Son v. Shaw, 277 Ill. 524, 115 N.E. 650 (1917) (officers); McGuire v. Outdoor Life Publishing Co., 311 Ill. App. 267, 35 N.E.2d 817 (1941) (officers). Acceptance of this concept was voiced by Ladd, Liability of Individuals Conducting the Affairs of a Foreign Corporation Not Authorized To Do Business in Iowa, 15 IowA L. REv. 285, 297-98, 304-06 (1930).

${ }_{137}$ E.g., Taylor v. A. G. Branham \& Co., 35 Fla. 297, 17 So. 552 (1895) (shareholders); Equitable Trust Co. v. Central Trust Co., 145 Tenn. 148, 239 S.W. 171 (1921) (shareholders).

138 Ladd, supra note 136, at 301 , argued against such an extension.

139 Towle v. Beistle, 97 Ind. App. 241, 186 N.E. 344 (1933) (shareholders);

Shawmut Commercial Paper Co. v. Auerbach, 214 Mass. 363, 101 N.E. 1000 (1913) (officers).

140 American Soap Co. v. Bogue, 114 Ohio St. 149, 150 N.E. 743 (1926) (president-manager-director). The case required a new solution, for application of the "nonexistent principal" theory would have circumvented an otherwise valid bankruptcy.

141 Note, 41 Yale L.J. 309 (1931). Minor defects in compliance have not subjected even active officials to personal liability where other sanctions were provided. See Walsh v. Hallstead, $140 \mathrm{~Pa}$. Super. 13, $13 \mathrm{~A} .2 \mathrm{~d} 95$ (1940) (failure to register change of name).

$142 \mathrm{~A}$ criticism of judicial reliance on formal labels is found in Note, 19 CoRN. L.Q. 90, 94-95 (1933). Acknowledging the inadequacies of personal liability, one 
Recently, the number of suits to impose liability on associates with regard to corporate obligations has diminished considerably. Statutes in some states still make certain individuals financially responsible, ${ }^{143}$ but only two post-1940 suits involving such responsibility for the transactions of undomesticated corporations have been found. ${ }^{144}$

The lack of recent reported decisions on this question might be explained by several factors. The broadening of the "doing business" concept has enabled local citizens and creditors more readily to secure local service of process on and, assuming solvency, pecuniary relief from the corporation itself. Statutes are more explicit in describing the circumstances in which recovery may be had, and against whom, thereby limiting the incidence of recourse to higher state tribunals. Resort to bankruptcy has become more common for distressed associations; local creditors with more opportunities to press their claims at such proceedings are not forced to initiate their own suits. Finally, there is a trend toward restricting the liability of corporate officials in other areas of litigation which could conceivably influence creditors' conduct in this matter. ${ }^{145}$ Despite these attempts at explanation, it must be noted that a thorough investigation focused on this particular question is necessary before a completely satisfying answer can be given.

author still argued that the technique did protect local citizens from insolvent or illegal operations. Ladd, supra note 136 , at 305 . Solvent enterprises, it was thought, would be estopped to deny their noncompliance, and there would be no need to sue individual associates. Insolvent enterprises would be deterred from entering the state by the fear that associates would be held personally liable. But courts often rejected the first argument in the most aggravated cases. See American Soap Co. v. Bogue, 114 Ohio St. 149, 150 N.E. 743 (1926). And the first argument could not be persuasive so long as courts were unwilling to restrict a creditor to an action against the corporation in the first instance. See Joseph T. Ryerson \& Son v. Shaw, 277 III. 524,115 N.E. 650 (1917).

143 See note 133 supra.

144 In Marian Realty Co. v. Cibel, 321 Mass. 480, 73 N.E.2d 902 (1947), a landlord brought suit against a corporation's president for rent the corporation had failed to pay during a period of noncompliance. A statute declared officers liable on contracts "so long as such failure [to domesticate] continues." Recovery was allowed, although the statute permitted the defect to be cured by subsequent compliance and the corporation had complied; the court said liability was fixed as of the time of the transaction. A sounder ground for this decision might have been that the lease was made between the landlord and the president personally, without agreement or apparent intent to look exclusively to the corporation for the rent upon its later domestication. In the other case, McGuire v. Outdoor Life Publishing Co., 311 IIl. App. 267, 35 N.E.2d 817 (1941), the court reluctantly held the officers of a foreign corporation liable to a former employee for damages for breach of an employment contract because the contract was entered into prior to an enactment designed to reverse the state's personal liability rule. See also the following cases which arose from the extension of credit in Arkansas to a defectively incorporated association and involved the personal liability of the "de facto" corporation's shareholders who resided outside the state: Whitaker v. Mitchell Mfg. Co., 219 Ark. 779, 244 S.W. 2d 965 (1952); Doggrell v. Great So. Box Co., 206 F.2d 671 (6th Cir.), rev'd on rehearing, 208 F.2d 310 (6th Cir. 1953); Paper Prod. Co. v. Doggrell, 195 Tenn. 581, 261 S.W.2d 127 (1953).

145 See generally Feuer, Liabilities of Directors and Officers, 5 N.Y.L.F. 235, 276-77 (1959). 


\section{Curability of Defects by Subsequent Domestication}

As has been indicated, a number of the early statutes controlling the domestication of foreign corporations declared their contracts and acts prior to compliance wholly void. ${ }^{148}$ Whether or not they were interpreted as preventing enforcement by both parties, it was generally conceded that insofar as the corporation could not sue on such a contract, it could never put itself in a position to do so by later acts. ${ }^{147}$ The corporation "being an outlaw at the beginning of the case . . . must so continue throughout." 148 Where the statute declared that no suit could be maintained on contracts made by a noncomplying foreign corporation, the same result obtained. ${ }^{149}$

Today a majority of the states provide that a corporation's compliance with the domestication statute will cure any disability that might otherwise be imposed. ${ }^{150}$ The language used differs ${ }^{151}$ but the intent does notthe strongest deterrent ${ }^{152}$ to doing local business illegally can be removed

146 See note 56 sipra.

147 E.g., Republic Power \& Serv. Co. v. Gus Blass Co., 165 Ark. 163, 263 S.W. 785 (1924); Perkins Mfg. Co. v. Clinton Constr. Co., 211 Cal. 228, 295 Pac. 1 (1930).

148 Amalgamated Zinc \& Lead Co. v. Bay State Zinc Mining Co., 221 Mo. 7, 18, 120 S.W. 31, 35 (1909).

149 E.g., United Lead Co. v. J. W. Reedy Elevator Mfg. Co., 222 Ill. 199, 78 N.E. 567 (1906); E. C. Vogt, Inc. v. Ganley Bros., 185 Minn. 442,242 N.W. 338 (1932). In Hutterian Brethren v. Haas, 116 F. Supp. 37 (D. Mont. 1953), the relevant statute provided that no contract was enforceable until the corporation complied. This was construed to mean compliance was a condition precedent to doing business, not to bringing suit. The latter construction was rejected as "a flat contradiction." The court distinguished other cases allowing subsequent compliance to cure the disability on the ground that Montana's statute also contained penal provisions which labelled the conduct a misdemeanor. This suggested to the court that the conduct was prohibited. This analysis is not generally followed, see note 66 supra and accompanying text. One case carried the prohibition against suit to an extreme for which the only explanation is an oversolicitude for a state agency. In Newell Contracting Co. v. State Highway Comm'n, 195 Miss. 395, 15 So. 2d 700 (1943), on a suit to collect for extra work required by the state on a highway construction contract, plaintiff's domestication when the work was two-thirds done was not allowed to cure the disability to sue, this despite the fact that noncompliance was first raised as a defense after the case had been pending for three years and plaintiff, after twenty days of taking testimony, had rested its case.

150 E.g., Cal. Corp. Code $\S 6801$; Nev. Rev. Stat. $\$ 80.170$ (1957); see Unlicensed Foreign Corporations-Enforcement of Contracts, 20 CoRP. J. 223 (1953). An interesting example of the effect of such legislation is provided by the Pittsburgh Constr. Co. litigation. The company had been barred in a federal court from maintaining suit on a contract. Pittsburgh Constr. Co. v. West Side Belt R.R., 154 Fed. 929 (3d Cir. 1907). After compliance and a change of Pennsylvania law the state court held the defect to be cured and permitted the suit. Pittsburgh Constr. Co. v. West Side Belt R.R., 227 Pa. 90, 75 Atl. 1029 (1910), aff'd, 219 U.S. 92 (1911).

151 No suit may be maintained on intrastate transactions, e.g., "until" compliance, CAL. CORP. CODE $\$ 6801$, "unless" domestication occurs before tria1, N.C. GEN. STAT. \$55-154(a) (1960), "without having complied," W. VA. CoDE ANN. § 3091 (1955), or "so long as" there is a failure to comply, ME. REv. STAT. ANN. ch. 53, 128 (1954). Statutory changes in "style or phraseology" have been held to work no substantive change in the right to cure the disability. Compare Outdoor Elec. Advertising, Inc. v. Saurage, 207 La. 344, 21 So. 2d 375 (1945) ("unless and until"), and Swift \& Co. v. Little, 28 R.I. 108, 65 Atl. 615 (1907) ("unless"), with J. R. Watkins Co. v. Floyd, 119 So. 2d 164 (La. Ct. App. 1960) ("unless"), and Garst v. Canfield, 44 R.I. 220, 116 Atl. 482 (1922) ("so long as").

152 See note 47 supra and accompanying text. 
before final judgment is entered, and the offending corporation can benefit from these transactions. ${ }^{153}$ It is common to find courts labelling these provisions as creating a "plea in abatement" ${ }^{154}$ or a "dilatory exception" 155 or as "suspending the remedy." 158 Among the more common explanations for such provisions are those which stress the injustice imposed on a corporation by an absolute bar ${ }^{157}$ and those which see the domestication law as an attempt to place foreign corporations on a par with domestic ones in terms of availability of information and amenability to process. ${ }^{158}$

One matter regarding curability which was once a source of conflict is the interpretation of the word "maintain" in the prohibitory statutes. ${ }^{159}$ Although infrequently a court still construes this to mean "begin" or "initiate" suit, ${ }^{180}$ it is generally held to its literal meaning, that upon the plea of noncompliance being entered the suit can no longer be "maintained," but that it may be freely instituted.101 Several consequences may follow from this interpretation. For one, foreign corporations may be encouraged to do intrastate business while undomesticated, assuming the risk that if they eventually need the services of the local courts they may have to pay a penalty and accrued fees. ${ }^{162}$ The disability need be of concern only if it is invoked in litigation. For another, a statute which merely defers the time of trial and provides the local citizen with no substantive defense against a foreign corporation is not likely to be invoked with regularity. Such a statute fails as a weapon when the state delegates its enforcement to defendants, since they cannot be relied upon to abate suits if delay is not in their best interests. Thus corporate offenders, both the crafty and the

153 No state provides that subsequent compliance absolves the corporation of penalties. Indeed, some require the payment of back fines before compliance. See statutes cited note 162 infra.

154 Leonard Advertising Co. v. Flagg, $128 \mathrm{Me}$ 433, 148 Atl. 561 (1930).

155 Outdoor Elec. Advertising, Inc. v. Saurage, 207 La. 344, 21 So. $2 d 375$ (1945). This phrase, of course, is unique to Louisiana's civil law practice.

156 Niblack v. Seaberg Hotel Co., 42 N.M. 281, 76 P.2d 1156 (1938).

157 Protective Fin. Corp. v. Glass, 100 N.J.L. 85, 125 Atl. 879 (Sup. Ct. 1924); see Comment, 59 Y ALE L.J. 737, 746 (1950).

158 E.g., Hill-Lanham, Inc. v. Lightview Dev. Corp., 163 F. Supp. 475 (D.D.C. 1957) ; cf. Humphry v. City Nat'l Bank, 190 Ind. 293, 130 N.E. 273 (1921). The common acceptance of posttransaction curability is suggested by recent decisions which do not even bother to offer any explanation. See, e.g., Ammann v. St. Joe Paper Co., 341 S.W.2d 700 (Tex. Civ. App. 1960).

159 See, e.g., N.Y. GeN. CoRP. LAw \$ 218.

160 See Hutterian Brethren v. Haas, 116 F. Supp. 37 (D. Mont. 1953) (dictum).

161 See Hill-Lanham, Inc. v. Lightview Dev. Corp., 163 F. Supp. 475 (D.D.C. 1957); Ward Land \& Stock Co. v. Mapes, 147 Cal. 747, 82 Pac. 426 (1905); Burton v. Oliver Farm Equip. Sales Co., 121 Fla. 148, 163 So. 468 (1935); National Fertilizer Co. v. Fall River Five Cents Sav. Bank, 196 Mass. 458, 82 N.E. 671 (1907). In Southern Bell Tel. \& Tel. Co. v. State ex rel. Transradio Press Serv., Inc., $5 \dot{3}$ So. 2d 863 (Fla. 1951), plaintiff successfully ran out and filed for domestication when its noncompliance was pleaded at trial.

162 See, e.g., Car. Corp. Code \$6801; Onio Rev. Code Ann. \$1703.29 (Page 1954). It is clear that the majority of business activities of any corporation never come to litigation. On the other hand, the assessment of risk must also include possible penal provisions imposed for carrying on unlicensed corporate activity. See note 133 stipra and accompanying text. 
inadvertent, may remain undetected indefinitely-the desired information unobtained and revenue lost. There is no ready resolution of the desire to be fair to foreign corporations by allowing subsequent compliance to cure defects and the necessity to stimulate the uncovering of noncompliance by making the plea of noncompliance attractive. ${ }^{163}$ One answer might be to give private litigants bonuses for detecting noncomplying corporations. This could be done by building on those provisions that allow noncompliance to be pleaded in abatement and require back fees and penalties to be paid as a prerequisite to domestication. Defendants who have forced compliance by their abating plea could be given a percentage of the accrued amounts. Such a reward would strike a balance between the two competing objectives, although paying a gratuity to defendants in civil suits might seem objectionable to some. Obviously it is novel to pay, in effect, a subsidy to defendants, but if the payment is viewed as a reward for uncovering lawbreakers within the state, it is no more startling than any other reward for the apprehension of criminals or the provisions for treble damages under the federal antitrust laws. ${ }^{\mathbf{1 6}}$

An important question in the application of subsequent compliance statutes is the period within which such compliance will be effective. Thus, where by statute no suit was permitted on any cause of action "so long as" there was noncompliance, the time of accrual of the cause of action was the governing factor, and suit was allowed for overpayment on a contract made before compliance, because the overpayment was not discovered until the time of settlement-which was after compliance. ${ }^{165}$ Similarly, a contract was upheld against a charge of invalidity where the corporation conducted no business in the state prior to entering into the contract and compliance followed the contract by little more than a month. ${ }^{166}$ In the preceding examples, the defendant evidently suffered no prejudice from the corporation's tardiness in complying. The corporation may not expect lenity if it postpones compliance so long that the defendant is likely to be inconvenienced. Thus, in E. \& G. Theatre Co. v. Greene, ${ }^{167}$ the corporation was granted eighteen days to act or face dismissal, and upon its failure the

163 Against the objectionable possibility that just obligations might be avoided if noncompliance were an affirmative defense must be weighed the administrative impossibility of having the state primarily responsible for detecting corporate intruders. The practical difficulties inherent in state enforcement have led to the reliance on litigants, through the maintenance-of-suit disability, to enforce the domestication laws.

164 Clayton Act $\S 4,38$ Stat. 731 (1914), 15 U.S.C. $\S 15$ (1958).

165 Peoples Wet Wash Laundry Co. v. Dubeau, 80 N.H. 544, 119 Atl. 706 (1923).

166 Will v. City of Bismarck, 36 N.D. 570, 589, 163 N.W. 550, 556 (1917); cf. Jamison v. Franklin Life Ins. Co., 60 Ariz. 308, 317-18, 136 P.2d 265, 269 (1943), in which mortgagee domesticated shortly before taking title to property following default on loans made by the mortgagee while still undomesticated. The Jamison court followed Woodward v. Fox W. Coast Theaters, 36 Ariz. 251, 260, 284 Pac. 350,353 (1930), which held that a lease executed by a then domesticated foreign corporation was not affected by the fact that compliance came after the negotiations leading to the making of the lease.

167216 Mass. 171, 103 N.E. 301 (1913). 
affirming court stated that "in view of its persistent refusal to abide by the requirements of our law it must suffer the consequence . . and cannot avail itself of the benefit of our court." 168

\section{ConClusion}

The picture of state control of undomesticated foreign corporations presents anything but a uniform pattern for analysis. State legislatures and courts have built their systems through a trial and error process of penalization and toleration, of rigidity and flexibility - with an occasional loan from a neighboring sovereign. Old laws have cluttered the statute books, working in some cases to impede and in others to enhance the development of an internally consistent policy. Some states seem to have had no unified policy over the years. To find patterns or trends within this maze is conjectural at best, and those seemingly discerned sometimes lack empirical endorsement.

Considerable gloss has been added to the statutes of some states, while others have required only occasional judicial construction. In part this reflects no more than the incidence and volume of local commercial activity. But this explanation fails to account for the grouping of Florida, Arkansas, and Louisiana, with New York, Illinois, and Texas, as states with great numbers of reported cases in this area. Other factors must be present. One which may be suggested is that the more intricate the statute or its use of conceptual terminology, the greater the need and demand for judicial elaboration. Although this cannot be conclusively demonstrated, it is supported by comparing the experience of New York and Arkansas. New York has long operated on a bare skeleton of a regulatory statute ${ }^{169}$ and the incidence of litigation has not been disproportionate to its importance as a commercial center, whereas Arkansas, with a detailed statute, which bristles with prohibitions and penalties ${ }^{170}$-probably reflecting a generally more hostile attitude toward foreign corporations-has had a thriving volume of litigation. On the other hand, New Jersey's retaliatory statute, ${ }^{\mathbf{1 7 1}}$ requiring the courts to apply both New Jersey law and whatever harsher law may be in force in the state where the offending corporation is incorporated, has not spawned an inordinate amount of litigation.

The initial determinant in all noncompliance situations is the presence or absence of intrastate activity. Despite occasional crystallizations of specifics, either by statute or by settled judicial interpretation, this area remains extremely unpredictable. However, the uncertainties of the "doing business" concept apparently have not given rise to the application of

$108 \mathrm{Id}$. at $174,103 \mathrm{~N} . \mathrm{E}$. at 302 . Despite the sharp words accompanying the dismissal it is unclear whether the plaintiff would be barred from bringing an action after compliance.

169 N.Y. GEN. CoRp. LAW §§ 210, 218-19.

170 See Ark. Stat. Ann. §§64-1201 to -05 (1957).

171 N.J. Stat. ANN. $\$ 14: 15-5$ (1939) ; see Babe Kaufman Music Corp. v. Mandia, 127 N.J. Eq. 480, 13 A.2d 790 (Ch. 1940). 
different criteria among different classes of suits-contract, tort, replevin, and so forth. The variations occur only in the categories incident to the implementation of the statute, such as penalty collection, qualification in order to maintain suit, and amenability to service of process. While different criteria could be established for different kinds of actions, their possible value is questionable, and no tendency in that direction is presently discernible. The developments have been, and are likely to remain, largely ad hoc.

The success of large fines, actively enforced, as a method of barring corporate intruders is neither proven nor refuted by the evidence presently available. But it does seem that, to the extent they could serve this function, fines have not kept pace with inflation and the expansion of corporate entities. In many states they are so small as to be inconsequential. If it can be demonstrated that there is in fact a deterrent element to penaltiesthough it must be recalled that some states ignore this possibility ${ }^{172}$ - they should be brought to a level commensurate with the financial resources of offenders. A figure once established should be reviewed periodically to see that it is still capable of achieving its purpose. Another observation which may be made is that the efficacy of the domestication statutes is dependent on stringent enforcement of these and other sanctions. While the state may be unable to afford the price of rigorous initial detection, once uncovered, the offender must be subjected to the full force of the statute. Compliance will not be achieved through undue solicitude for the plight of the self-styled unwitting offender, its officers, and its agents.

The maintenance-of-suit disability has apparently been the most important sanction in the enforcement of domestication statutes. This will almost certainly continue to be true, but the frequency of its invocation is likely to diminish in the many states where subsequent compliance can cure defects. Since the volume of intrastate activity by foreign corporations is unlikely to lessen, the states will have either to fall back on relatively unused provisions or to enact new ones to protect their interests. Or, as a deliberate choice, violators may be tolerated in the belief that their activities within the state produce returns in other forms-such as by stimulating vitality in the business climate of certain communities-to a degree which outweighs the difficulties of enforcing compliance and the benefits gained from such action.

A. J. E.

172 E.g., Colorado, New York, and Vermont, none of which provide for a monetary penalty. 